Illinois State University

ISU ReD: Research and eData

Theses and Dissertations

3-28-2019

\title{
Redline Erased: U.S. Foreign Policy in Syria and the Criteria for Humanitarian Intervention
}

Caroline A. Kernan

Illinois State University, ckernan6895@gmail.com

Follow this and additional works at: https://ir.library.illinoisstate.edu/etd

Part of the International Relations Commons

\section{Recommended Citation}

Kernan, Caroline A., "Redline Erased: U.S. Foreign Policy in Syria and the Criteria for Humanitarian Intervention" (2019). Theses and Dissertations. 1081.

https://ir.library.illinoisstate.edu/etd/1081

This Thesis is brought to you for free and open access by ISU ReD: Research and eData. It has been accepted for inclusion in Theses and Dissertations by an authorized administrator of ISU ReD: Research and eData. For more information, please contact ISUReD@ilstu.edu. 


\section{REDLINE ERASED: U.S. FOREIGN POLICY IN SYRIA AND THE CRITERIA FOR HUMANITARIAN INTERVENTION}

\section{CAROLINE A. KERNAN}

100 Pages

The United States' involvement in the Syrian conflict remains rather contentious and unclear. The world is currently experiencing the worst refugee crisis since World War II due to the ongoing Syrian conflict which has produced approximately 6 million refugees. The United States' actions in the Syrian conflict may have prolonged this refugee crisis by refusing to take a more hardline stance in the conflict against Syrian President Bashar Al-Assad's regime. While the United States has acted in Syria, it is much more limited in comparison to that of the recent Libyan intervention. The Libyan intervention serves as a basis for contemporary U.S. military interventions rooted in humanitarian concern and helps shed light on U.S. decision-making and

foreign policy with regards to Syria. Both the Libyan and Syrian conflicts were explored through the theoretical framework of social network theory in order to identify networks within each conflict, the actors within said network, and how their behavior and decision-making processes are influenced. Four criteria found in the Libyan intervention, namely altruism, an international legal basis, the involvement of NATO, and domestic public support were applied to the Syrian conflict to determine if humanitarian intervention will take place in Syria. The four criteria were not found to be present in the Syrian conflict and it appears humanitarian intervention is unlikely to happen going forward. Inferences may be made arguing that since the invasion of Iraq, U.S. 
interventions have adhered to realism and self-serving interests in comparison to past interventions born of liberalism and humanitarian concern.

KEYWORDS: Social Network Theory; Libyan Intervention; Syrian Conflict; Humanitarian Intervention; U.S. Foreign Policy 
REDLINE ERASED: U.S. FOREIGN POLICY IN SYRIA AND THE CRITERIA FOR HUMANITARIAN INTERVENTION

CAROLINE A. KERNAN

A Thesis Submitted in Partial

Fulfillment of the Requirements

for the Degree of

MASTER OF SCIENCE

Department of Politics and Government

ILLINOIS STATE UNIVERSITY

2019 
Copyright 2019 Caroline A. Kernan 


\section{REDLINE ERASED: U.S. FOREIGN POLICY IN SYRIA AND THE CRITERIA FOR HUMANITARIAN INTERVENTION}

CAROLINE A. KERNAN

COMMITTEE MEMBERS:

Noha Shawki, Chair

Ali Riaz

LJ Zigerell 


\section{CONTENTS}

Page

CHAPTER I: INTRODUCTION 1

CHAPTER II: LITERATURE REVIEW

Existing Literature on the Syrian Conflict 3

Past Determinations of U.S. Intervention $\quad 5$

$\begin{array}{ll}\text { Theoretical Framework } & 7\end{array}$

CHAPTER III: METHODOLOGY 15

CHAPTER IV: HUMANITARIAN INTERVENTION IN LIBYA 21

CHAPTER V: CASE STUDY: THE COMPLEXITY OF THE SYRIAN CONFLICT 37

Syrian Conflict Background \& Context 37

U.S. Involvement in Syria \& Theoretical Relevance $\quad 40$

CHAPTER VI: ANALYSIS

Humanitarian Intervention in Libya $\quad 55$

SNT Principle 1: Nodes are mutually dependent and influence each

other's behavior $\quad 55$

SNT Principle 2: Ties between nodes serve as channels for the

transmission of goods and information within networks 61

SNT Principle 3: Ties within a given network have the ability to create structures which may influence nodes' behavior $\quad 66$

$\begin{array}{ll}\text { Syrian Conflict Case Study } & 69\end{array}$

SNT Principle 1: Nodes are mutually dependent and influence each

other's behavior 
SNT Principle 2: Ties between nodes serve as channels for the transmission of goods and information within networks

SNT Principle 3: Ties within a given network have the ability to create structures which may influence nodes' behavior

Criteria for Humanitarian Intervention in Syria 


\section{CHAPTER I: INTRODUCTION}

The United States has a long track record of military intervention and regime change across the globe, most notably in Latin America, but more recently in the Middle East. While their involvement in foreign conflicts and humanitarian crises has not always been bad, it has been rather complacent at times with regards to their level of involvement and watching as humanitarian crises unfold around them. Through their arming of rebel groups and propping up of corrupt regimes, the United States has their fair share of blood on their hands as it pertains to military interventions and invasions. The United States is not always averse to taking an active role in humanitarian intervention, as noted by their recent military intervention in Libya in 2011, but is Libya the standard, or the exception? It still remains rather unclear under what conditions human rights and humanitarian concerns for refugees trump other U.S. interests during interventions, especially with regards to the Syrian conflict and ongoing refugee crisis, which this paper seeks to address. Egregious human rights violations have taken place under the guise of war in the Syrian conflict, but little has been done to prevent future abuses. The United States attempted to intervene on humanitarian grounds years ago, but their objectives have since shifted towards the War on Terror and humanitarian concerns appear to have fallen by the wayside. An ample amount of research has been conducted on the Syrian refugee crisis as of late due to the ongoing Syrian civil war and the War on Terror; however, the intricacies of this conflict are still not fully understood.

Research on the complex relationships within this conflict often overlooks some of the most important causes of the existing conflict and persecution of civilians. Much of the research looks at this conflict from the inside out and fails to address the possibility that external forces may be exacerbating a domestic conflict. By focusing on the domestic causes of the war and not 
addressing the relationships between involved actors, as well as their relations with actors outside of the conflict, it limits the scope of research and the understanding of the conflict. The conflict in Syria can no longer be looked at as a civil war, but rather as a growing regional war being fought within Syrian borders. While context and domestic histories are vital to understanding the root causes of this conflict, they do not always adequately explain how this crisis is being prolonged.

There is little research on how cooperation between superpowers, especially the United States, and other countries involved in this conflict may exacerbate the crisis by either turning a blind-eye to the atrocities being committed or by refusing to take military action against Syrian President Bashar al-Assad. The research is also sparse with regards to alliances within this conflict and what factors drive their decision-making. This thesis seeks to fill the gaps in the literature by answering the following questions: Why has the United States not increased their level of involvement, particularly through the use of violence, in order to prevent the prolongation of the Syrian refugee crisis, and under what circumstances do human rights and humanitarian concerns for refugees trump other U.S. interests? 


\section{CHAPTER II: LITERATURE REVIEW}

\section{Existing Literature on the Syrian Conflict}

Much of the existing literature on the Syrian conflict strictly pertains to the Arab Spring uprisings and protests, or specific facets within the war, and fails to provide an allencompassing approach of the relations between actors. The RAND Corporation has come the closest to such an observation by discussing the most notable dynamics within the conflict, especially the reluctance of the United States to enter into the conflict. They note such hesitance by stating "Future historians will no doubt debate whether a less timid United States... might have preserved the dominance of the democratic secularists and hastened Assad's downfall." If the United States had taken a different approach, it may have led to a swift removal of Assad and prevented the infiltration of ISIS into Syria. However, due to the complexity of the conflict, it is difficult to assert such a definitive claim. RAND's study does not discuss in detail the complexity of the conflict, rather, it provides a brief overview of the contributing factors to the war. While identifying these factors is of the utmost importance in order to understand the conflict, it may provide only a limited understanding since the relations between involved actors are not addressed.

Instead, the RAND Corporation focuses on the multiple potential outcomes of the war as it pertains to the contributing factors, namely U.S. involvement, the spread of ISIS, and any future legal basis. According to Brian Michael Jenkins from the RAND Corporation, the constant state of fighting "is not likely to provoke military intervention.... The world's moral outrage has been blunted by the seemingly endless images of Arabs and Muslims killing one another."2

\footnotetext{
${ }^{1}$ Brian Michael Jenkins, “The Dynamics of Syria's Civil War,” RAND Corporation, 2014, 14, https://www.rand.org/content/dam/rand/pubs/perspectives/PE100/PE115/RAND_PE115.pdf ${ }^{2}$ Ibid.
} 
While this sentiment may be partially true since many people have become numb to the atrocities in Syria because they have become so commonplace, it does a great disservice to political research to assume that intervention should be deemed highly unlikely because of one reason alone. Setting altruism aside, when discussing the possibility of intervention and the removal of Syrian President Bashar Al-Assad, Jenkins continues to remain pessimistic. According to Jenkins, due to "the dynamic situation, assessments have short lives," meaning inferences made about the conflict are short-lived due to the complex and ever-changing nature of the war. ${ }^{3}$ The inability to make concrete conclusions on assessments alone raises the question: why has more research not been conducted on the relations between involved actors within the conflict in order to understand behavioral constraints?

The RAND Corporation's research provides insightful information, but it lacks substantive explanations. Other researchers have attempted to explain the Syrian conflict through its origins as a civil war, but they fail to address the importance of external factors on the war as it has become a regional conflict. Research conducted by Jose Ciro Martinez and Brent Eng focuses on domestic Syrian relations within the war and how they have unraveled over almost a decade of violence. While understanding the relevance of welfare, the impact of food shortages, and the successes/failures of Assad's military are important in order to understand the current state of Syria, they do not help explain international relations and the implications of foreign policy. Their study did help contribute to the literature regarding the rise of ISIS in the country, but it did not explain how the role of ISIS has impacted other actors within the conflict. ${ }^{4}$ Similarly, Ingrid Habets addresses ISIS and obstacles to peacebuilding within the conflict, but

\footnotetext{
${ }^{3}$ Ibid.

${ }^{4}$ Jose Ciro Martinez \& Brent Eng, "Struggling to Perform the State: The Politics of Bread in the Syrian Civil War," International Political Sociology, vol. 11, 2017, 141, https://academic.oup.com/ips/articleabstract/11/2/130/2875287
} 
does not look at how the actions of involved actors guides others. Habets does note that "The war in Syria cannot be seen as black and white. It is no longer merely a war between a dictator and its citizens." Habets provides good information and insight as to why peace seems unattainable, but her work lacks further explanation. Since there are a number of actors at play within the conflict, and it is impossible to please them all, it is important to understand the interests of each actor and how they affect the interests of others, as well as their foreign policy. Once these interests are taken into consideration in conjuncture with existing relations within the conflict, inferences may be made.

Identifying the multiple causes of the conflict is vital, but providing only a fraction of an explanation as to why such events occurred may do more harm than good. The existing literature is not inaccurate, rather, it is incomplete. Explanations should not always be taken at face value, especially when there are a number of overlapping interests involved that make such an explanation more complex. By looking at the Syrian conflict and potential intervention through the lens of an applicable theoretical framework, the conflict may be better understood.

\section{Past Determinations of U.S. Intervention}

Two prominent political science camps, liberals and realists, have often disputed the underlying reasons for past U.S. interventions. Liberals tend to argue that the United States has intervened abroad in order to protect refugees and victims of human rights abuse while realists contend military action is only taken in instances when U.S. interests are threatened. The political scientist Seung-Whan Choi conducted an empirical study in which he concludes U.S. interventions are utilized in the event of needing to preserve human rights and liberal norms. ${ }^{6}$ In

\footnotetext{
${ }^{5}$ Ingrid Habets, "Obstacles to a Syrian peace: the interference of interests," European View, vol. 155, 2016, 79, https://journals.sagepub.com/doi/pdf/10.1007/s12290-016-0397-3

${ }^{6}$ Seung-Whan Choi, "What determines US humanitarian intervention?" Conflict Management and Peace Studies, vol. 3(2), 2013, 121.
} 
his study, Dr. Whan Choi describes humanitarian intervention as "an intervention conducted by a US military force in conjunction with a humanitarian mission.." Dr. Whan Choi also clarifies the definition of military intervention the study relies on "as the movement of the regular troops or forces of one country into the territory or territorial waters of another country." ${ }^{8}$ However, his research only looks at U.S. humanitarian and military interventions between the years of 19812005 and fails to look at motives of the United States' most recent interventions or how the invasion of Iraq has since shaped policy.

According to the political scientist Richard Little, "intervention has always been and remains an imprecise and extremely ambiguous concept." ${ }^{\text {"9 }}$ Due to the inherent misconceptions and ambiguity of interventions, this may explain the prominent concept of mission creep and shifting motives that often plague interventions. Little also notes that interventions will become increasingly more complex as globalization continues to spread and technological advancements are made, especially with regards to economically motivated interventions. He argues that due to "the growth of transnationalism and interdependence, attention is going to be focused much more closely in the future on interventions against the national norm of non-intervention." ${ }^{10}$ In addition, it is the concept of non-intervention that leads to the confusion surrounding many interventions. Governments often attempt to camouflage their acts with regards to intervention, which further complicates matters and results in ambiguity as objectives are not overtly clear to both those involved and those watching the conflict unfold. ${ }^{11}$ While Little addresses the definitions associated with intervention and the way different international relations theorists

\footnotetext{
7 Ibid., 123.

${ }^{8}$ Ibid.

${ }^{9}$ Richard Little, "Revisiting intervention: a survey of recent developments," Review of International Studies, vol. 13(1), January 1987, 49, https://www.jstor.org/stable/20097100?seq=1\#metadata_info_tab_contents

10 Ibid., 58.

${ }^{11}$ Ibid., 49.
} 
explore these conflicts, he does not attempt to explain the underlying causes of recent interventions according to those theories.

In Dr. Whan Choi's research, he concludes that the United States typically adheres to the liberal approach and prioritizes humanitarian concerns over political and economic reasons. ${ }^{12}$ However, the realist approach may be more applicable to U.S. interventions from the last decade. Realists contend that morality has little to no effect on military engagements and that humanitarian interventions are nothing more than political tools used to achieve national security and economic interests. ${ }^{13}$ If humanitarian concerns alone are the reason for intervention, as Dr. Whan Choi argues, than how can the Syrian conflict be explained? While aspects of a military intervention are present, there is currently not an ongoing humanitarian intervention.

\section{Theoretical Framework}

The theoretical framework of Social Network Theory has been used to understand international conflict and cooperation between states for the last few decades, but is still relatively underutilized in the field of peace and conflict studies. The theory has been incorporated into research in the social sciences to better understand the relations between social units in the international system, namely individuals, organizations, and states. The primary assumption of social network theory is that nodes, which are the actors in a network, and ties, the existing relations between said actors, can be used to explain networks effects in international relations and the globalization process, particularly in violent conflicts. The theory is based upon three main principles: nodes are mutually dependent and influence each other's behavior; ties between nodes serve as channels for the transmission of goods and information within networks;

\footnotetext{
${ }^{12}$ Seung-Whan Choi, "What determines US humanitarian intervention?" Conflict Management and Peace Studies, vol. 3(2), 2013, 128.

${ }^{13}$ Ibid., 124.
} 
ties within a given network have the ability to create structures which may influence nodes' behavior. ${ }^{14}$ Social network theory argues that states are social actors "in which social rules will constrain or constitute a state policy" and that states act according to the social interactions of "individual actors and organizational and associational complexity." ${ }^{15}$ In accordance with this theory, states will attempt to act on their own behalf, but their actions are often constrained by network ties, limiting their behavior. Phenomena must be addressed according to both the individual state and its relevant social networks. In this case, the application of social network theory may answer the following question: why has the United States refrained from using a higher level of force in the Syrian conflict, and why has the United States not prioritized humanitarian concerns in Syria?

When studying a violent conflict, such as the Syrian war, it cannot simply be analyzed by comparing the resources and military capacities of involved actors. Violent conflicts must be analyzed by "studying the interactions between the different individual nodes that make up the actors themselves." ${ }^{\prime 6}$ All phenomena within the conflict must be analyzed in order to fully understand the intended actions of the individual actors as well as the impact of their actions within their social networks. According to the political scientist Christian Kramer, "it is the interaction, competition, and cooperation between individual bodies that make up the system itself." ${ }^{17}$ Kramer notes that complex social networks are not hierarchical and are non-linear, arguing that a multitude of simple processes, or interactions, run parallel to each other and affect each other in complex systems all while lacking a controlling authority. However, multiple

\footnotetext{
${ }^{14}$ Lieke 't Gilde, "Social Network Theory in International Relations Research," January 2014, 7-8, http://arno.uvt.nl/show.cgi?fid=133127

${ }^{15}$ Ibid., 8.

${ }^{16}$ Christian Kramer, Network Theory and Violent Conflicts: Studies in Afghanistan and Lebanon, (Cham: Springer Nature, 2017), 8.

${ }^{17}$ Ibid., 6.
} 
systems may appear within a given phenomenon by reaching a point of bifurcation when systems become too unpredictable or rigid. According to Kramer, "Life is thus 'the balance between forces of order and forces of disorder, between fixed rigid structures and chaotic motion." ${ }^{18}$ However, this concept is not new. Networks and systems can be found as far back as the ancient Roman and Greek empires. Social network theory just recently gained international attention in the social sciences due to uneven globalization and a growing complexity amongst networks that has eroded traditional structures and brought about a new state of awareness due to constant technological advancements that further promote interconnectivity between societies. ${ }^{19}$ The political scientist Alvin Wolfe seemingly concurs with this sentiment, arguing that this awareness allows for a greater application of the network concept to human problems. He states, "Network analysis helps us to understand social processes in complex systems and it can help us specifically to locate potential conflicts, provide early warning of barriers to communication and of developing bottlenecks in resource allocation."20 Through this analysis, measures can be taken to address "structural holes" in networks and strategic inferences can be made for involved actors. ${ }^{21}$ This analysis may also be used to address hierarchical structures that were not previously known in order to resolve conflicts and to promote peacebuilding efforts. ${ }^{22}$ Even though networks are not inherently fixed structures or hierarchical, it does not mean that actors are equal within the conflict. Due to asymmetrical relations within conflicts actors will not remain truly equal within a conflict network regardless of a hierarchical structure.

\footnotetext{
18 Ibid., 5.

19 Ibid., 27.

${ }^{20}$ Alvin Wolfe \& Yang Honggang, Anthropological Contributions to Conflict Resolution, (Athens: University of Georgia Press, 1996), 7-8.

${ }^{21}$ Alvin Wolfe, "Network Thinking in Peace and Conflict Studies, Peace and Conflict Studies, vol. 11(1), 2004, 72, https://nsuworks.nova.edu/cgi/viewcontent.cgi?referer=https://www.google.com/\&httpsredir=1\&article=1045\&cont ext $=$ pcs

22 Ibid., 73.
} 
There is a myriad of ways networks may be formed, which is vital to note in order to properly analyze them. According to sociologist Charles Kadushin, "A Network is simply a set of relations between objects which could be people, organizations, nations, items found in a Google search, brain cells, or electrical transformers." ${ }^{" 23}$ To put it simply: networks can be found everywhere and have the potential to grow out of almost anything. The Spanish sociologist Manuel Castells goes a step further by arguing that the world itself is actually a Network Society due to all of human life being organized into "global networks: financial markets; transnational production; ... the mass media; the Internet networks; .. international institutions; religion; $\ldots$ and the transnational NGOs and social movements that assert the rights and values of a new global civil society." ${ }^{24}$ Each of these networks is made up of individual nodes that are susceptible to change and altered behavior. However, since these nodes and their values are in a constant state of flux, they are increasingly susceptible to violence and resistance. Noting the plethora of ways networks are created and their susceptibility to violence is important when studying violent conflicts. The root causes of conflicts are often rather ambiguous, so noting the possible ways in which a relationship can sour are important for expanding the scope of research. According to Castells, "These communities often become trenches of resistance against a social order perceived as alien and imposed by force, when the institutions that used to provide security (the state, the church, the family) no longer function properly. ${ }^{.25}$ Understanding the root causes of resistance and the networks in which these movements flourish in is vital to understanding conflicts that were born out of resistance movements, such as the Syrian conflict. When resistance or conflict breaks out, it tends to create a ripple effect since networks are unlimited

\footnotetext{
${ }^{23}$ Charles Kadushin, Understanding Social Networks: Theories, Concepts, and Findings, (Oxford: Oxford University Press, 2012), 3.

${ }^{24}$ Manuel Castells, Communication Power, (Oxford: Oxford University Press, 2009), 25.

${ }^{25}$ Ibid., 362.
} 
and lack definitive borders, which can be attributed to the ever-growing complexity of the Syrian conflict. Protests against an abusive regime rapidly turned into a civil war, and have since become a regional conflict with half a dozen proxy wars that are spurring the violence in Syria toward an impending cataclysm.

When societal boundaries and networks change, they have the potential to alter the flows of power and the structure of other networks due to their inherent interconnectivity. Due to this instability, it is nearly impossible to pinpoint power relations, unless it is in hindsight. These relations, or ties, are constantly changing and do not take place in a vacuum, which makes it increasingly difficult to explain power changes within ongoing violent conflicts, such as Syria. However, hindsight from previous, contemporary conflicts, with similar nodes, such as the recent intervention in Libya, may make it easier to come to potential conclusions with regards to violent conflict. By analyzing complex networks, the structures of international relations within each network, and causal mechanisms, conflict and cooperation may be better understood in comparison to traditional models that often overlook these intricacies. ${ }^{26}$

Communication is vital to the sustainability of networks, but since all actors may not speak the same language, communication can mean a number of things. One of the most common forms of communication is violence because it is something that all actors within a network are familiar with and understand, and it has the potential to create a sense of belonging or identity. ${ }^{27}$ However, there are obvious negative side effects to violence, namely it "destroys the ability of nodes to compromise... violence becomes perpetual. Its close relation to honour leads to a reinforcement of group identity that prevents reconciliation and instead favors

\footnotetext{
${ }^{26}$ Han Dorussen, Erik Gartzke, and Oliver Westerwinter, "Networked international politics: Complex interdependence and the diffusion of conflict and peace," Journal of Peace Research, vol. 55(3), 2016, 289.

${ }^{27}$ Christian Kramer, Network Theory and Violent Conflicts: Studies in Afghanistan and Lebanon, (Cham: Springer Nature, 2017), 20.
} 
confrontation." 28 Violence comes in many forms and does not necessarily have to be achieved through physical force, and the same goes for the concept of war. For example, the Syrian conflict has taken on multiple definitions of war and violence because the causes of the conflict remain somewhat ambiguous. Different concepts of war may be found in the conflict, particularly the War on Terror which has most recently been invoked by the United States and other western countries. "A 'war on terror' is more of a populist rallying cry, rather than a signal to physically pick up weapons and fight." ${ }^{29}$ If the War on Terror is just a rallying cry and not meant to be representative of actual war, which may appear to be true due to President Trump's recent decision to remove troops from Syria since ISIS has allegedly been defeated in the region, then how has U.S. involvement in the region shifted from moderate intervention due to an ongoing humanitarian crisis to an abstract War on Terror? Addressing the shift in U.S. foreign policy and its ties with other nodes in the Syrian conflict network is vital to understanding when humanitarian concerns become a top priority for the United States and how the conflict may end. It is also important to note the different concepts and definitions of war within the Syrian conflict due to the complexity of the phenomenon and the number of different actors that are at war for various reasons so that peacebuilding efforts or humanitarian intervention may begin.

Peacebuilding attempts often worsen violent conflicts, but this is because the causes of the conflict are not fully understood. ${ }^{30}$ When peacebuilding attempts are implemented, they are often done poorly because the assumed causes of the conflict are inaccurate; therefore, offering incorrect solutions to the ambiguous causes of the ongoing violence. In addition, peacebuilding

\footnotetext{
${ }^{28}$ Ibid.,

${ }^{29}$ Christian Kramer, Network Theory and Violent Conflicts: Studies in Afghanistan and Lebanon, (Cham: Springer Nature, 2017), 13.

${ }^{30}$ Edward Newman \& Oliver Richmond, "Peace building and spoilers," Conflict, Security \& Development, vol. 6(1), 2006, 101, DOI: 10.1080/14678800600590728
} 
attempts may often fail because actors perceived as willing to promote peace are actually attempting to 'spoil' peacebuilding efforts. According to the political scientists Edward Newman and Oliver Richmond, “Groups which seek to 'spoil' efforts to resolve conflict often do so because they see the peace process as undermining their rights, privileges, or access to resources, whether physical, strategic, or political."31 The apparent unwillingness of the United States to promote peacebuilding efforts, to engage in the use of violence in order to prevent further violence, or to implement a military intervention based on humanitarian concerns, may be attributed to a lack of understanding of the conflict as a whole. According to Kramer, "The only way to provide clarity to both the concepts of war and peace, as well as to allow them to be used as notions in international relations, is to focus on the surrounding discourse." 32 This is where social network theory comes in.

According to political scientists Han Dorussen, Erik Gartzke, and Oliver Westerwinter, the theoretical framework of social network theory "help[s] illuminate the causes and consequences of conflict they allow researchers to develop a better understanding of the causal dynamics and structural geometry of the complex web of interdependencies at work in the onset, incidence, and diffusion of conflict and peace." ${ }^{33}$ By highlighting interdependencies and the effects of ties between nodes, the actions of nodes, specifically the United States, within the Syrian conflict can be better understood. The apparent decision to withhold humanitarian assistance or to deploy more troops may not have been preferred U.S. foreign policy; rather, it may be the consequence of relational constraints within their network in Syria. According to

\footnotetext{
${ }^{31}$ Ibid., 108.

${ }^{32}$ Christian Kramer, Network Theory and Violent Conflicts: Studies in Afghanistan and Lebanon, (Cham: Springer Nature, 2017), 17.

${ }^{33}$ Han Dorussen, Erik Gartzke, and Oliver Westerwinter, "Networked international politics: Complex interdependence and the diffusion of conflict and peace," Journal of Peace Research, vol. 55(3), $2016,284$.
} 
Wolfe, there is no other form of analysis as effective at determining inferences regarding complex social systems in violent conflict as that of social network theory. "What could be more important for a program of conflict prevention or a program of conflict resolution than to know the degrees to which particular portions of a total system are, or are becoming, relatively isolated from the rest?"34 In order to fully understand why the United States has refrained from using violence in Syria and when humanitarian concerns trump other interests, the situation that led up to intervention in Libya must be addressed and the ongoing conflict in Syria and all of its interconnected networks must be explored.

\footnotetext{
${ }^{34}$ Alvin Wolfe, "Network Thinking in Peace and Conflict Studies, Peace and Conflict Studies, vol. 11(1), 2004, 7374, https://nsuworks.nova.edu/cgi/viewcontent.cgi?referer=https://www.google.com/\&httpsredir=1\&article=1045\& context=pcs
} 


\section{CHAPTER III: METHODOLOGY}

In order to understand the role that interconnected networks play in foreign policy decisions, especially regarding humanitarian concerns trumping other interests, it is prudent to conduct a case study that will highlight all relations within a given conflict. This research will address U.S. foreign policy with regards to Syria, as well as the interconnected networks within the Syrian conflict and how they affect U.S. decision-making, particularly with regards to humanitarian intervention. U.S. foreign policy in Syria will then be compared to the latest humanitarian intervention in Libya in order to test the necessary criteria for humanitarian intervention in Syria. Libya is being used as the basis for contemporary U.S. intervention because of its similarities to the Syrian case study and because the timelines between the two overlap. Both the Libyan and Syrian conflicts find their roots in the 2011 Arab Spring, born out of protests against oppressive regimes and started during President Obama's first term, which make comparing foreign policy decisions easier since they were carried out by the same administration. The lack of humanitarian intervention in Syria may even be attributed to the decision to intervene in Libya, which may have spread thin the military capabilities of the great powers. A better understanding of the Libyan conflict and intervention will provide insight into the current situation in Syria and how it has grown into such a complex phenomenon, and has the potential to shed light on the United States' Middle Eastern policy.

The qualitative case study methodology was chosen for this thesis because of its ability to take complex phenomena, such as the Syrian conflict, and study and evaluate them within their proper contexts. Even though there are similarities between the Libyan and Syrian conflicts, they are still two entirely different conflicts that need to be looked at as contextual so that all intricacies within the conflicts may be addressed. Case studies allow "the researcher to explore 
individuals or organizations, simple through complex interventions, relationships, communities, or programs and supports the deconstruction and the subsequent reconstruction of various phenomena. ${ }^{35}$ In addition, the case study method was chosen for this thesis because of its ability to extensively explain a specific case, especially as it pertains to theory-based research. There are multiple definitions used when referring to case studies, but this research will be done according to the definition provided by political scientist John Gerring. He argues that case studies are "best defined as an intensive study of a single unit with an aim to generalize across a larger set of units," and any inference from a case study can be considered either illustrative or falsifiable. ${ }^{36}$ Single unit case studies, such as this one, are able to test causal implications of a theory; therefore, they are able to provide a causal argument. ${ }^{37}$ Since the Syrian conflict is becoming increasingly more complex and expansive, it is vital that a methodology that is capable of looking at the multifaceted nature of such a conflict be applied in accordance with social network theory. Case studies are most often used to answer "how" or "why" questions, particularly when the behavior of actors within the study cannot be manipulated, conditions within the study are contextual, and there are no clear boundaries with regards to the phenomenon and context. ${ }^{38}$ This thesis seeks to answer why the United States has refrained from using violence in the Syrian conflict and under what conditions will humanitarian concerns trump other U.S. interests. In addition, the conditions of the Syrian conflict are extremely contextual due to the ever-growing

\footnotetext{
${ }^{35}$ Pamela Baxter \& Susan Jack, "Qualitative Case Study Methodology: Study Resign and Implementation for Novice Researchers," The Qualitative Report, vol. 13(4), December 1, 2008, 544, https://nsuworks.nova.edu/cgi/viewcontent.cgi?article $=1573 \&$ context $=$ tqr ${ }^{36}$ John Gerring, "What Is a Case Study and What Is It Good for?" The American Political Science Review, vol. 98(2), 2004, 352, https://www-jstor-org.libproxy.lib.ilstu.edu/stable/pdf/4145316.pdf?refreqid=excelsior\%3Ae05 $\mathrm{e} 05 \mathrm{c} 3 \mathrm{~b} 36 \mathrm{ac} 4 \mathrm{f} 764 \mathrm{fdd} 458 \mathrm{~cd} 2796 \mathrm{eb}$

${ }^{37}$ Ibid., 348.

${ }^{38}$ Pamela Baxter \& Susan Jack, "Qualitative Case Study Methodology: Study Resign and Implementation for Novice Researchers," The Qualitative Report, vol. 13(4), December 1, 2008, 545, https://nsuworks.nova.edu/cgi/viewcontent.cgi?article $=1573 \&$ context $=$ tqr
} 
complex nature of the war. Since this case study is researching an ongoing war, the states and organizations involved in the study cannot be manipulated through this research. Lastly, the boundaries with regards to the phenomenon that is the Syrian conflict and the underlying context of the situation are unclear, which is why the Syrian conflict will be compared to the U.S. invasion in Libya.

The illustrative method will be used because of its ability to take the aforementioned case study and incorporate it into the theoretical framework of social network theory. Illustrative case studies are descriptive in nature and are useful for comparing situations so that conclusions may be drawn with regards to specific instances, such as the Syrian conflict, and may help explain context and information that readers are unfamiliar with. ${ }^{39}$ The main pitfall of illustrative case studies is that they require extensive research, which is actually beneficial for this thesis. According to Bruce Mann, "There are pitfalls in presenting illustrative case studies. They require presentation of in-depth information of each illustration... The cases must adequately represent the situation or program." ${ }^{40}$ Since the Syrian conflict is so complex, it requires extensive research to explain what causes are prolonging the conflict, as well as research on the ever-growing list of involved actors and their relations with each other. In addition, the illustrative method is beneficial for this research since it may be used to explain the necessary criteria for humanitarian intervention that was prevalent in Libya and apply it to the Syrian case study. Sine the case study revolves around foreign policy and political decision-making with regards to the Middle East, it is vital that the method of this case study be able to explain such policies in detail so that intricacies within policy and their effects on these conflicts are not overlooked.

\footnotetext{
${ }^{39}$ Lynn Davey, "The Application of Case Study Evaluations," Practical Assessment, Research \& Evaluation, vol. 2(9), 1991, 1, https://pareonline.net/getvn.asp? $\mathrm{v}=2 \& \mathrm{n}=9$

${ }^{40}$ Bruce Mann, Selected Styles in Web-Based Educational Research, (Hershey: Information Science Publishing, 2006), 72 .
} 
Since this is a theory-based thesis, social network theory must be proven to be relevant within the given case study. The illustrative method is only capable of looking at a small number of instances, so it may be hard to conclude without generalizing; however, any conclusion will be beneficial in understanding how social network theory can explain the causes of violent conflict and shed light on decision-making processes with regards to U.S. foreign policy and humanitarian intervention. ${ }^{41}$ While other qualitative methods may have been suitable for this study, namely the exploratory method, they were not the most applicable due to their inability to be used in longitudinal studies. ${ }^{42}$ Since the case study looks at an ongoing refugee crisis and conflict over a specific timeframe, it is a requirement for this study that the chosen method may be applied over a period of time. The illustrative method is best suited for this research topic because of its ability to incorporate observations with regards to policy/relations, the environment, and actors in the Syrian conflict within the framework of social network theory. The method is only applicable to a small number of case studies, which is why this study is only looking at one ongoing conflict. ${ }^{43}$

A qualitative research method was chosen over quantitative research due to the illustrative method's ability to collect data in a way that does not need to be broken down into numbers or statistics. According to John Van Maanen, qualitative research relies on data that is "symbolic, contextually embedded, cryptic, and reflexive" and allows "researchers to identify such symbols, and as a way of assessing their meaning, to record the pattern of responses these symbols elicit." ${ }^{44}$ Furthermore, qualitative research helps contextualize culture and behavior. In

\footnotetext{
${ }^{41}$ Richard Hayes, Brittany Kyer, \& Emily Weber, "The Case Study Cookbook," December 2105, 8-9, https://web.wpi.edu/Pubs/E-project/Available/E-project-121615-164731/unrestricted/USPTO_CookbookFinal.pdf 
order to understand the actions and behavior of politicians, governments, terrorist organizations, and rebels in the Syrian conflict, as well as their organizational experiences, their experiences and history must be described. Qualitative research, specifically the illustrative method, can do just that. According to Van Maanen, “The assessment of an organization's environment as an illustrative substantive domain... [is] desirable to assess an organization's environment in qualitative terms" and some researchers in this field are prematurely "pushed toward the quantification of environmental concepts without giving due consideration to the meaning of the concepts they measure. ${ }^{45}$ With regards to the Syrian conflict, the concepts and policies being measured must first be addressed qualitatively in order for them to be fully understood, but one day they be quantified in order to provide an all-encompassing conclusion.

The Syrian conflict and refugee crisis were chosen because the United States' involvement in the conflict is rather contested and has sparked a debate on whether or not the United States should be involved, or if they have done enough as a superpower to end the conflict. In addition, the United States' relations with actors on either side of the conflict has raised red flags throughout this study as to what is really guiding the United States' moral compass and decision-making process with regards to military involvement and aid to refugees and displaced Syrians. The illustrative method will be able to highlight concerns regarding issuelinkage between involved actors and their impact on foreign policy, as well as how these issues affect relations/ties between actors, and the roles the conflict has created with regards to involved international organizations, particularly the United Nations and varying humanitarian efforts. Even though the Syrian case study will be compared to the recent U.S. military intervention in Libya, Libya will not be considered a case study. The Libyan intervention will serve as a guide

\footnotetext{
${ }^{45}$ Ibid., 524.
} 
for the Syrian case study in order to highlight similarities or differences and what that means for future humanitarian intervention in Syria. This case study seeks to understand why the United States has refrained from using violence in Syria and under what conditions they will intervene in order to prioritize humanitarian concerns over other U.S. interests. 


\section{CHAPTER IV: HUMANITARIAN INTERVENTION IN LIBYA}

Both the Libyan and Syrian civil wars were grounded in Arab Spring revolts that rapidly spread across the Middle East and Northern Africa in the early 2010s. Muamar Gaddafi had served as a figurehead in Libyan politics for nearly half a century, but he did not face any serious backlash until 2011 when Libyans began protesting decades of human rights violations perpetrated by his government. It was not uncommon for dissenters to disappear or to end up in jail, where torture and murder were prevalent. ${ }^{46}$ There was not a free press in Libya, so social media played a major role in spreading awareness of such atrocities and the mobilization of antiGaddafi movements across Libya, as well as protests calling for democracy across the Middle East. President Obama and his administration had been grappling with how to handle these uprisings throughout the region and initially wanted to take a more hands-off approach before ultimately deciding to intervene. However, on March 19, 2011, the Obama Administration launched Operation Odyssey Dawn (OOD) against Gaddafi and other Libyan military targets. ${ }^{47}$ The United States was in a rather precarious situation as they were still heavily involved in two wars, Iraq and Afghanistan, and the Obama Administration was facing heavy domestic backlash from a war-weary country that felt it was not their place to involve themselves in yet another war. However, humanitarian intervention happened anyways due to the severity of the human rights violations perpetrated by the Gaddafi regime.

There were numerous necessary conditions involved that made intervention in Libya possible, which may or may not be relevant to the Syrian conflict as well. The United

\footnotetext{
46 "Report of the Working Group on the Universal Periodic Review: Libyan Arab Jamahiriya," United Nations General Assembly, January 4, 2011, 13, 20, https:/www2.ohchr.org/english/bodies/hrcouncil/docs/16session/AHRC-16-15.pdf

${ }^{47}$ Mikael Blomdahl, “Interacting Interests: Explaining President Obama’s Libyan Decision,” European Journal of American Studies, vol. 13(2), 2018, 1. https://journals.openedition.org/ejas/13224
} 
States was not willing to intervene on altruistic humanitarian means alone; rather, the United States needed something to gain from such an intervention. One of the most important factors with regards to intervention in Libya was international support. U.S. allies, primarily France and Britain, were willing to act against Gaddafi's regime and explicitly sought help from the United States. Since the United States is allies with France and the UK, they essentially have their own network that has the potential to pull each node into other networks as they see fit. Due to their close relations, their foreign policy decisions are often mutually dependent upon either and impacted by each other's decisions. The United States had initially attempted to adopt a 'wait and see approach,' but this rapidly changed once NATO and the UN backed U.S. intervention. According to Secretary of State Hillary Clinton, the backing from the UN was "a watershed moment in international decision-making." 48 Surprisingly, the Arab League was also in favor of the implementation of a no-fly zone and humanitarian intervention from Western countries, something the League has typically opposed.

The Secretary General of Hezbollah, Hassan Nasrallah, and Sunni cleric, Yousef alQaradawi of the Muslim Brotherhood, were also unlikely sources of support for intervention. Similarly, support from the Arab League and prominent Islamist figures was influential to U.S. decision-making because they no longer had to worry about working against them within the conflict, rather they incorporated them into their conflict network. Many researchers accredit the League's support of intervention to Qaddafi and the Libyan government's “inability to sell it as 'a colonial Crusader' war." 49 On March 17, 2011, the Security Council at the UN passed UNSC Resolution 1973, "which authorized a no-fly zone and the use of all means necessary short of

\footnotetext{
${ }^{48}$ Scott Horsley, "U.S. Intervention in Libya: A Noble Use of Force?” NPR, March 28, 2011, https:/www.npr.org/2011/03/28/134927059/u-s-intervention-in-libya-a-noble-use-of-force 49 Shibley Telhami, "Libya Action in U.S. National Interest," Brookings, March 28, 2011, https://www.brookings.edu/opinions/libya-action-in-u-s-national-interest/
} 
foreign occupation to protect civilians. ${ }^{, 5051}$ President Obama defended his decision in a speech by stating, "We knew that... if we waited one more day, Benghazi, a city nearly the size of Charlotte, could suffer a massacre that would have reverberated across the region and stained the conscience of the world," further bolstering claims of intervention along humanitarian lines. ${ }^{52}$ However, despite an overwhelming amount of international support for humanitarian intervention, only 13 percent of Americans were willing to commit ground troops to Libya. ${ }^{53}$ Due to low public support, the Obama Administration continued to downplay involvement in the Libyan conflict and claimed to be taking a supporting role. According to a speech given by President Obama, "We should not be afraid to act—-but the burden of action should not be America's alone. As we have in Libya, our task is instead to mobilize the international community for collective action." ${ }^{, 54}$ Yet, the Obama Administration simultaneously refuted claims that the United States had 'led from behind' as officials felt it discredited U.S. leadership abroad. Obama's Deputy National Security Advisor Ben Rhodes argued, "If we were to sit this one out, it would have sent a signal that the U.S. isn't really a leader." 55 Since U.S. allies had already committed troops to the region, it would not have boded well for the United States to not act. The strategic move to allow the UK and France to take control may have been an attempt by the United States to place themselves lower in the Libyan conflict hierarchy. In doing so, it

\footnotetext{
${ }^{50}$ Mikael Blomdahl, "Interacting Interests: Explaining President Obama's Libyan Decision," European Journal of American Studies, vol. 13(2), 2018, 6. https://journals.openedition.org/ejas/13224

51 "S/RES/1973," Security Council Report, March 17, 2011, https://www.securitycouncilreport.org/un-documents/document/Libya-S-RES-1973.php

52 A. Trevor Thrall, "Libya and the 5 Stages of U.S. Intervention, The National Interest, April 19, 2016, https://nationalinterest.org/blog/the-skeptics/libya-the-5-stages-us-intervention-15826

53 "Public Wary of Military Intervention in Libya: Broad Concern that US Military is Overcommitted," Pew Research Center, March 14, 2011, http://www.people-press.org/2011/03/14/public-wary-of-military-intervention-inlibya/

${ }^{54}$ Barack Obama, "Speech Given at the National Defense University," March 28, 2011, http://www.whitehouse.gov/the-press-office/2011/03/28/remarks-president-address-nation-libya

55 James Mann, The Obamians: The Struggle Within the White House to Redefine American Power, (New York: Penguin Group, 2012), 293.
} 
would lessen their responsibility in the matter and leave them less vulnerable to attack.

According to political scientist Mikael Blomdahl, U.S. involvement in Libya essentially relied on a combination of four factors: altruism; the legality of intervention and international support; domestic constraints and public support; the ability to shift responsibility to NATO. ${ }^{56}$ If a combination of these factors are present in the Syrian case study, there may be an argument for U.S. intervention in Syria, or it may provide greater insight as to why there has not been greater U.S. involvement in the conflict.

Over the last few years, intervention in Libya has become a point of contention. Scholars have widely debated whether or not intervention was the right choice and if NATO's intervention subsequently caused the civil war that began in 2014 , or if other factors were at play. In order for an adequate comparison to the Syrian case study to be made, a more in-depth analysis of the Libyan intervention is needed. The first Libyan civil war began on February $17^{\text {th }}$, 2011 and quickly caught the attention of Ban Ki-moon, the UN Secretary General. By February $21^{\text {st }}$, rebels ceased control of Libya's second largest city, Benghazi, and Ban met with Gaddafi to discuss a ceasefire; however, Gaddafi refused to give up his power and expressed his wish to die a "martyr." 57 After Ban's meeting with Gaddafi, the UN issued a statement declaring antiGaddafi demonstrations in Libya as legitimate and exposed human rights violations committed by the Gaddafi regime. Shortly after, violence continued to escalate and the UN again called on Gaddafi to take responsibility for the disarray in Libya in order to protect his own citizens. In accordance with the concept of responsibility to protect (R2P), a global commitment endorsed by all UN member states, a country must take responsibility for the protection of its population, and

\footnotetext{
${ }^{56}$ Mikael Blomdahl, “Interacting Interests: Explaining President Obama's Libyan Decision,” European Journal of American Studies, vol. 13(2), 2018, 10, https://journals.openedition.org/ejas/13224

${ }^{57}$ James Meikle \& Ian Black, "Muammar Gaddafi says he will die a martyr rather than quit," The Guardian, February 22, 2011, https:/www.theguardian.com/world/2011/feb/22/muammar-gaddafi-libyan-tv-martyr
} 
if it fails to do so, it must accept support from outside states. ${ }^{58}$ Gaddafi failed to adhere to R2P, which resulted in the adoption of two resolutions at the UN that called for military intervention in order to protect Libya's civilian population.

The Security Council first passed Resolution 1970 on February 26, 2011, which imposed an arms embargo as well as target sanctions that froze assets and implemented a travel ban. ${ }^{59}$ The Security Council quickly expanded upon this resolution and passed Resolution 1973 on March 17, 2011, which installed a no-fly zone over Libya and strengthened the existing sanctions from Resolution 1970. ${ }^{60}$ These two resolutions laid the groundwork for Member States, primarily members of NATO, "to take all necessary measures... to protect civilians" in Libya from Gaddafi and the Libyan Arab Jamahiriya short of foreign occupation due to the implicit underlying of R2P ${ }^{61}$ By March 31, 2011, all NATO allies agreed to enforce the no-fly zone and initiated Operation Unified Protector, an expansion of the no-fly zone that created an internationally recognized military intervention that would not end until October 31, 2011. However, the United States had not been as eager as its NATO allies to intervene in Libya.

President Obama had been hesitant to intervene in another Middle Eastern country due to ongoing wars in Iraq and Afghanistan. He came into office promising to end the revolving door of U.S. involvement in the Middle East, yet he was hardly able to end the War in Iraq without immediately involving the U.S. in Libya and Syria. However, Obama's aversion to foreign entanglements appears to have contributed to the prolongation of the aforementioned conflicts.

\footnotetext{
${ }^{58}$ Marcus Cadier, "World in Conflict - The Case of Libya, The United Nations \& NATO," The University of Gothenburg - Institution of Global Studies, August 16, 2016, https:/gupea.ub.gu.se/bitstream/2077/52328/1/gupea 2077_52328_1.pdf

59 “S/RES/1970," Security Council Report, February 26, 2011, https://www.securitycouncilreport.org/undocuments/document/libya-s-res-1970.php

60 “S/RES/1973," Security Council Report, March 17, 2011, https://www.securitycouncilreport.org/undocuments/document/Libya-S-RES-1973.php

61 "Resolution 1973 (2011)," United Nations Security Council, March 17, 2011, 3, https://www.nato.int/nato_static/assets/pdf/pdf_2011_03/20110927_110311-UNSCR-1973.pdf
} 
He was determined to keep his promise to the American public that he would not follow in the footsteps of his predecessor and immerse the United States in yet another war like Iraq or a hasty call to arms like Afghanistan that have both proved to be costly and counterproductive. However, despite much debate within the Obama Administration, the United States entered into Libya rather quickly. There were only three weeks between Secretary of State Hillary Clinton's acknowledgement of potential U.S. military involvement in Libya and President Obama's announcement that the United States would be upholding the UN and NATO's no-fly zone and implementing a modified no-drive zone. ${ }^{62}$ The rush into intervention may be attributed to the actions of other nodes within the conflict, namely the UK and France. Franco-British forces were eager to intervene in Libya, so their quick response may have been influential in pushing the Obama Administration into entering the conflict. Intervention would have also been expedited in comparison to past interventions since the majority of the nodes involved in the conflict were members of either the UNSC or NATO, which would have accelerated the transmission of information between nodes.

The transmission of information between individual nodes within the Obama Administration may have also expedited action since so many high-ranking officials and advisors were in favor of intervention. Secretary Clinton was monumental in molding the Obama Administration's foreign policy with regards to Libya, along with National Security Advisor and former U.S. Ambassador to the UN Susan Rice and her UN successor Samantha Power. Defense Secretary Robert Gates noted that it was Secretary Clinton's support for intervention in Libya that swayed President Obama in a "51-49" decision. ${ }^{63}$ Clinton, Power, and Rice became known

\footnotetext{
${ }^{62}$ Jo Becker \& Scott Shane, "The Libya Gamble: Hillary Clinton, 'Smart Power' and a Dictator's Fall," The New York Times, February 27, 2016, https://www.nytimes.com/2016/02/28/us/politics/hillary-clinton-libya.html?_r=0 ${ }^{63}$ Ibid.,
} 
as the humanitarian interventionists, or liberals, in a realist administration, along with Michael McFaul the U.S. Ambassador to Russia and Anne-Marie Slaughter, who was the head of policy planning at the State Department. However, they were split between concerns for human rights and the spread of democracy. While humanitarian concerns were noted, interventionists, particularly McFaul, began to push democracy heavy rhetoric in order to shake the assumption that President Obama was a realist, rather than him being a strong proponent of democracy that just so happened to be surrounded by realists. ${ }^{64}$ According to McFaul, military force produced "limited results for democracy in Afghanistan and Iraq, but tainted the world. The Bush record, however, cannot be cited as a reason to abandon the project altogether."65 If Obama and his Administration were realists, they would have accepted the world, particularly Libya, as it was, they would not have attempted to make it into something that it is not but that they wish it was, i.e. a democracy, unless it advanced the interests of the United States. By implementing McFaul's rhetoric on democracy into speeches, it made the Obama Administration seem altruistic and idealistic. Due to R2P, military intervention in Libya was inherently altruistic, but altruism was not enough to persuade the United States to act.

The Obama Administration needed a justification for entering Libya, not just morally, but legally. The mistakes of the Bush Administration still lingered and Obama was reluctant to inherit Bush's legacy. The War in Iraq shaped Obama's foreign policy across the Middle East and may have even warped his worldview, leaving him hesitant of any future intervention out of fear of the implications any involvement would have on the U.S. Similarly, interventions in Iraq and Afghanistan impacted the way Middle Eastern countries viewed the United States and

\footnotetext{
${ }^{64}$ James Mann, The Obamians: The Struggle Within the White House to Redefine American Power, (New York: Penguin Group, 2012), 170.

${ }^{65}$ Ibid., 168.
} 
damaged ties in the region. The U.S. intervention in Iraq led to a civil war and America had no one to blame but themselves. If intervention in Libya were to go awry as well, it would potentially result in another costly ongoing war with no clear end in sight. However, if the United States were not responsible for the brunt of the consequences, it would leave room for the possibility of U.S. involvement. When two of the U.S.'s closest allies and fellow NATO members, France and Britain, asked for U.S. assistance, it helped persuade the Obama Administration to act. However, even when the United States decided to act alongside their allies, they continued to pretend that their action was strictly a supporting role in the conflict. The United States and the United Kingdom fired more than 110 missiles in late March 2011 while French planes attacked Gaddafi forces in Benghazi, yet President Obama continued to refer to it as "limited military action" within a "broad coalition" while his allies had no qualms about taking responsibility for their involvement. ${ }^{66}$ Obama's acknowledgement of U.S. involvement does not seem to match with Clinton's comments with fellow NATO members in which she states, 'It's crucial we're all on the same page on NATO's responsibility to enforce the no-fly zone and protect civilians in Libya." ${ }^{97}$ While they did agree to enforce the no-fly zone, it appears that they were not all on the same page and that there were some discrepancies with regards to an agreement on what level of action was deemed necessary.

France and the United Kingdom took a hardline approach and were quick to jump to regime change while the United States was willing to uphold UN resolutions, but was attempting to distance itself from another regime change narrative in the Middle East. The United Kingdom and France were the most adamant backers of military action in Libya, but the United States had

\footnotetext{
${ }^{66}$ Allan Little, "Libya: US, UK and France attack Gaddafi forces," British Broadcasting Company, March 20, 2011, https://www.bbc.com/mews/world-africa-12796972

${ }^{67}$ Micah Zenko, "The Big Lie about the Libyan War," Foreign Policy, March 22, 2016, https://foreignpolicy.com/2016/03/22/libya-and-the-myth-of-humanitarian-intervention/
} 
been dragging their feet with regards to making a decision about what level of involvement they wished to pursue. According to the former French Prime Minister, Alain Juppé, "Never mind that there's European impotence, but what about American power... Americans haven't defined their position. ${ }^{968}$ The United States entered Libya with the alleged intention of minimal involvement born out of humanitarian concerns due to Gaddafi's egregious human rights violations; however, the U.S. quickly became advocates of regime change for reasons that are not widely known.

According to political scientist Micah Zenko, researchers should treat "Libya as a case study for the ways that supposedly limited interventions tend to mushroom into campaigns for regime change. ${ }^{" 69}$ Similarly, the Libyan conflict illustrates the work of political scientist Richard Little who argued interventions are often too ambiguous and uncertain because of governments attempting to camouflage their true intentions, which then ultimately manifests itself into a mission creep. When the United States first entered Libya, President Obama, Assistant Secretary of State Philip Gordon, Deputy Secretary of State James Steinberg, Chairman of the Joint Chiefs of Staff Adm. Michael Mullen, and Secretary of Defense Robert Gates all issued statements denouncing the notion that the United States entered Libya for the purpose of regime change. On March 28, a week after the joint airstrikes against regime forces, President Obama addressed the course of action in Libya and declared that "Broadening our military mission to include regime change would be a mistake." ${ }^{70}$ However, in a span of roughly seven months, that was exactly what happened. There was little coverage on how the situation in Libya evolved so rapidly, but it

\footnotetext{
${ }^{68}$ Steven Erlanger, "France and Britain Lead Military Push on Libya," The New York Times, March 18, 2011, https://www.nytimes.com/2011/03/19/world/africa/19europe.html

${ }^{69}$ Micah Zenko, "The Big Lie about the Libyan War," Foreign Policy, March 22, 2016, https://foreignpolicy.com/2016/03/22/libya-and-the-myth-of-humanitarian-intervention/

${ }^{70}$ Barack Obama, "Remarks by the President in Address to the Nation on Libya," March 28, 2011, https://obamawhitehouse.archives.gov/the-press-office/2011/03/28/remarks-president-address-nation-libya
} 
may be attributed to low domestic support from Americans. In addition, the ambiguity of the intervention and the conflicting statements made by members of the Obama Administration may be attributed to the principles of SNT.

In the case that the United States was not attempting to camouflage their true intentions, it may be argued that objectives changed because they were influenced by other nodes within the conflict network, namely the UK and France. The United States would have been forced to shift from a smaller role in the conflict to one that more-so aligned with Franco-British hardliners. Shifting roles would have guaranteed the U.S. their place within the Libyan network hierarchy. However, this may not have been the case. The United States may have been camouflaging their true intentions all along in order to deflect responsibility from themselves. This masking of intentions would also explain the conflicting rhetoric that came from a number of members from the Obama Administration. The United States would have wanted to assure other nodes within the conflict that they would intervene, or U.S. officials at different events may have been influenced by individual nodes from countries the U.S. is allies with and were pressured into assuring them that they would intervene to a certain degree. If this is the case, the transmission of goods and information would have still taken place, but the transmission may have not been made public knowledge due to the camouflaging of intentions, which would explain the lack of media coverage on shifting objectives. By quietly shifting objectives, the U.S. was able to ensure their place within the Libyan network hierarchy without taking public responsibility for the effects of the intervention. Since the United States was concerned with the ability to shift responsibility to NATO upon entering Libya, it is plausible that the United States tried to create the impression that they were working in the background to assuage domestic public support concerns when in reality they were making influential decisions alongside the UK and France. 
America had become increasingly war weary after a decade of nonstop fighting in Iraq and Afghanistan and it was reflective in American support for future military action. According to Pew Research, 63 percent of Americans in 2011 believed the United States was not responsible for any military action in Libya, of which 51 percent of those polled attributed the lack of responsibility to U.S. forces already being overcommitted. Public support was so low that the majority of Americans strongly opposed even limited roles of military involvement in the country with only 13 percent of Americans in support of deploying ground troops. ${ }^{71}$ According to Gallup, polls regarding public support of airstrikes in Libya was 47 percent, which is remarkably lower than public support for all other recent military involvements in Iraq and Afghanistan that had approval ratings in the 70 s and $90 \mathrm{~s}^{72}$ A number of high ranking officials within the Obama Administration expressed their concerns regarding the lack of not only public support for military action in Libya, but also Congressional support, which resulted in a series of speeches from Obama where he repeatedly downplayed U.S. involvement. Obama attempted to drum up support in Congress with a March $21^{\text {st }}$ report claiming the use of force in Libya would be in the best interest of the U.S. as it would help prevent instability in the region and bolster the credibility of the UN Security Council. ${ }^{73}$

Public support has been key to past U.S. interventions; however, it played an alternative role in the Libyan intervention. The lack of support from Americans and Congress did not hinder intervention entirely, but served as a large domestic constraint on the course of operations within Libya and the overall scope of U.S. involvement. It appears that the lack of support was a large

\footnotetext{
71 "Public Wary of Military Intervention in Libya: Broad Concern that US Military is Overcommitted," Pew Research Center, March 14, 2011, http://www.people-press.org/2011/03/14/public-wary-of-military-intervention-inlibya/

72 Jeffrey M. Jones, “Americans Approve of Military Action Against Libya, 47 to 37\%” Gallup, March 22, 2011, https://news.gallup.com/poll/146738/americans-approve-military-action-against-libya.aspx

73 Barack Obama, "President Obama Speaks on the Turmoil in Libya: "This Violence Must Stop," The White House, Office of the Press Secretary, February 23, 2011.
} 
contributing factor as to why little information on the intervention and the shift towards regime change was made public record, as well as the hasty withdrawal from the country that ultimately led to a second civil war. The United States was attempting to publicly minimize their involvement in Libya both at home and abroad in order to avoid responsibility. The Obama Administration struggled with justifying the intervention to the American public, and to some extent the international community, since the intervention was of no vital interest to the United States and Washington was struggling to build political support. ${ }^{74}$ In addition, the perception of a power shift to NATO allowed for the U.S. to continue calling the shots in Libya as a dominant NATO member in the background while also seemingly removing the U.S. from the conflict. ${ }^{75}$ The United States had attempted to use media to garner public support for the NATO air campaign, also known as the "CNN Effect," by reporting the ongoing humanitarian crisis on real-time television in order to help shift policy by creating a rally effect among the American people. ${ }^{76}$ The coverage did initially provide a small rallying effect of public support, but it quickly fizzled out. Since the CNN Effect proved to be unsustainable, it may be argued that the United States' next solution to avoid lowering public support and damaging public perception of U.S. involvement was to avoid coverage altogether, which would explain the limited public record and minimization of involvement.

However, the United States was only able to withdraw from Libya so quickly because of the heavy involvement of NATO within the conflict. The United States was not only war weary, they were also rebounding from the Great Recession. The Department of Defense was facing

\footnotetext{
${ }^{74}$ Charles A. Kupchan \& Bernard Gwertzman, "Libya's Strains on NATO," Council on Foreign Relations, April 4, 2011, https://www.cfr.org/interview/libyas-strains-nato

${ }^{75}$ Ibid.,

${ }^{76}$ Lyse Doucet, "Syria \& the CNN Effect: What Role Does the Media Play in Policy-Making?" Daedalus: Journal of the American Academy of Arts \& Sciences, vol. 147(1), Winter 2018, https://www.mitpressjournals.org/doi/full/10.1162/DAED_a_00480
} 
serious spending cuts and attempting to handle the costly expenses that stemmed from the invasions of Iraq and Afghanistan, which placed another constraint on the U.S.'s ability to intervene. However, when NATO claimed full responsibility for the no-fly zone, it created an opportunity for U.S. involvement that would minimize the effects of any potential negative repercussions. The involvement of NATO, the Arab League, and non-NATO European states also fulfilled a longstanding claim of the Obama Administration to encourage our allies and other countries around the world to take greater responsibility with regards to global security, a concept also known as the responsibility doctrine. Obama emphasized the need for collective action with his March 28 speech in which he said, "we should not be afraid to act - but the burden of action should not be America's alone." 77 Since there were so many actors at play within Libya, it made the cost of operations much more affordable and allowed the Obama Administration to shake the notion that they were leading from behind. However, collective action was also beneficial because it allowed the United States to shift responsibility back onto NATO when intervention and military action no longer served their interests, essentially washing their hands of any wrongdoing.

Military intervention in Libya ended on October 31, 2011, less than two weeks after Gaddafi's death. Altruism appears to have been the necessary basis for considering intervention while the international legality stemming from UN resolutions and the involvement of NATO appear to have been key to the actual implementation of military involvement. However, military action and Obama's foreign policy with regards to Libya were greatly constrained by public and congressional support, economic factors, varying involvement of nodes within the conflict. There has been much debate on whether or not the intervention in Libya should be considered a failure,

\footnotetext{
${ }^{77}$ Obama, Barack, "Speech Given at the National Defense University," March 28, 2011, http://www.whitehouse.gov/the-press-office/2011/03/28/remarks-president-address-nation-libya
} 
or rather, if it was the quick withdrawal and lack of resources to build a stable democracy following intervention that are to blame for the failures of Libya today. It took less than three years after the end of the intervention in October 2011 for Libya to enter its second civil war. There are dozens of 'what ifs' that are used to explain how Libya could be if only this one thing had happened. Now that researchers have the benefit of hindsight, there have been a number of outspoken critics that blame the state of Libya today on the 2011 intervention. However, a number of political scientists, particularly Shadi Hamid, attribute the second Libyan civil war to the lack of resources to rebuild the country and implement a democracy after the intervention and not the intervention itself. In particular, Hamid notes the inability of the U.S. to deter its allies in the region from meddling in the fragile country in the small time between the end of the intervention and the onset of the second civil war. This inability to prevent allies from meddling may also be attributed to SNT. Due to the growing instability, Libya was left susceptible to further violence. Hamid argues that the intervention failed to produce a stable democracy because this "was never the goal. The goal was to protect civilians and prevent a massacre." While this sentiment is still controversial, it appears to be true, even if the United States were to have been looking for regime change from the start.

Since Power, Rice, and Clinton essentially crafted the bulk of foreign policy with regards to Libya, it should be worth noting that their desire for intervention was founded in humanitarian concerns, as well as UN Resolution 1973 that gave the international community the greenlight to intervene. McFaul was the interventionist that heavily focused on the implementation of a democracy and worked democratic rhetoric into President Obama's speeches in order to justify

\footnotetext{
${ }^{78}$ Shadi Hamid, "Everyone says the Libya intervention was a failure. They’re wrong." Brookings Institution, April 12, 2016, https://www.brookings.edu/blog/markaz/2016/04/12everyone-says-the-libyan-intervention-was-a-failuretheyre-wrong/
} 
intervention, so that may mean that democracy was not the underlying interest rather the facade used to garner public support. Hamid argues that it was the minimized approach to intervention, as well as the ensuing mission creep, that resulted in failure. The United States attempted to narrowly define their involvement in Libya, but gradually shifted their objectives and their military campaign, which made peacebuilding and the implementation of a stable democracy nearly impossible. The inconsistency of their military operations had a direct effect on peacebuilding efforts after the intervention because objectives remained unclear. If the United States and NATO had not intervened, Libya would surely be in a greater state of disarray than it is today, comparable to that of contemporary Syria. Gaddafi had referred to protestors as "cockroaches" and vowed in his speeches to cleanse Libya "inch by inch, house by house, home by home, alleyway by alleyway." United States had "not intervened, it's likely that Libya would be Syria... there would be more death, more disruption, more destruction." ${ }^{" 80}$ However, it would appear that the ghosts of previous interventions tend to linger and haunt contemporary foreign policy and the potential for future interventions. Intervention in Libya was minimized out of low public support due to the intervention in Iraq. Today, intervention in Syria appears to be a non-starter due to intervention in Libya and is often cited as what Libya would have become if intervention had not taken place. The adverse consequences of the Libyan intervention, as well as the additional cost of yet another military operation, tainted the possibility of another intervention within such a small timeframe. The War in Iraq warped Obama's worldview and how he handled foreign policy with regards to both Libya and Syria, and now it seems that Libya is warping the worldview and

\footnotetext{
${ }^{79}$ Ibid.,

${ }^{80}$ Thomas Friedman, "Obama on the World," The New York Times, August 8, 2014, https://www.nytimes.com/2014/08/09/opinion//president-obama-thomas-l-friedman-iraq-and-worldaffairs.html?_r=0
} 
foreign policy of Obama's successor as the Trump Administration attempts to handle the latest complex conflict in need of military action: Syria.

The Libyan conflict resulted in a humanitarian intervention because of pressure from nodes within the conflict network. The UK and France pressured not only the United States into intervening, but also Italy. Due to the influential nature of nodes within a network, the actions of each node within the conflict had a direct effect on other nodes within the network that they had ties with. The pursuit of intervention did result in the severing of a number of ties, but it was done in order to stack the structural hierarchy against Gaddafi and the Arab Jamahiriya. The severing of ties with Gaddafi is what ultimately led to his demise as Libyan ties that had previously been used for the transmission of goods, namely arms, and information ceased to exist. The ability of the international community to quickly come to a consensus and set a legal basis via the transmission of information between nodes at NATO, the UN, EU, and Arab League allowed for an expedited intervention and created a united front against Gaddafi. 


\section{CHAPTER V: CASE STUDY: THE COMPLEXITY OF THE SYRIAN CONFLICT Syrian Conflict Background \& Context}

Much like that of Libya, the Syrian conflict's roots may be found in the Arab Spring. The conflict began in 2011 when pro-democracy activists in Syria began protesting Bashar al Assad in an attempt to topple the Syrian president. Protests quickly turned into violent clashes between protestors and the government, which ultimately resulted in the formation of the Free Syrian Army (FSA) when rebel servicemen began to defect. The creation of the FSA spurred national protests towards civil war; however, international involvement and a growing number of actors has since made a domestic war much more complex. A pro-democracy protest has since become a widespread war rooted in economic interests, regional conflicts, potential religious divides, and the rise of terrorist organizations. Despite being a predominantly Sunni Muslim country, Syria's government is run predominantly by Alawites, which are a sect of Shia Islam. The original protests were not sectarian in nature, but appear to have eventually garnered sectarian support when war broke out. Regional Shia-majority governments, namely in Iran, Iraq, and Lebanon, began backing the Assad regime while the Sunni-majority countries of Turkey and Saudi Arabia came to the aid of the rebels. The divided support of these Muslim majority countries has prematurely been referred to as a religious proxy war, but requires further research in order to be adequately labeled. In addition to regional support, Russia has been backing Assad's regime in an attempt to protect Syria from ISIS; however, they have been targeting anti-Assad rebels that are backed by Western countries, particularly the United States. The United States formed an anti-ISIL coalition, of which Israel is a part, and has since been arming Syrian Kurds and other anti-Assad rebels. To complicate matters further, ISIL, Hezbollah, Jabhat Fateh al-Sham/AlNusra Front, and the Kurdish People's Protection Units (YPG) are also actively fighting within 
Syria. It is not the mere fact that numerous terrorist organizations are at play within the conflict and that the Syrian civil war has since morphed into a War on Terror that complicates the conflict, but the relations and ties these various organizations have since fostered since the onset of the war.

As a result of the ongoing conflict, there are 5.5 million Syrian refugees living outside of the country and more than 6 million internally displaced persons (IDPs) within Syrian borders. ${ }^{81}$ As if the Syrian conflict was not already complex enough, alliances between the United States and Russia and the United States and Turkey, as well as a growing number of proxy wars, are complicating matters further. Russia supports the Assad regime while the United States and Turkey support the rebels. This case study seeks to explore how having split interests and being members of multiple networks affects decision-making within the United States' foreign policy and how it impacts their role in Syria as a superpower. In addition, this paper seeks to address the four criteria listed by Mikael Blomdahl that are necessary to humanitarian intervention: altruism; the legality of intervention and international support; domestic constraints and public support; and the ability to shift responsibility to NATO. If these criteria are present, or possibly even a combination of the four, it may mean that humanitarian intervention in Syria is still possible. These criteria may also explain the recent shift from the United States' involvement due to Assad's human rights violations to the growing War on Terror and President Trump's claims that ISIS has been defeated and that U.S. involvement is no longer necessary.

Disarray in Syria is not a new phenomenon. The country was under emergency rule from 1963 to 2011, which caused large scale human rights violations that eventually erupted into civil

\footnotetext{
81 "Seven Facts About the Syria Crisis," United Nations High Commissioner for Refugees, March 2018, http://www.unhcr.org/ph/13418-seven-facts-syria-crisis.html
} 
war in $2011 .^{82}$ Assad became president in 2000 after the death of his father, Hafez Al-Assad, who was an oppressive authoritarian leader that attempted to secularize Syria. During Hafez AlAssad's reign, he attempted to eradicate the Muslim Brotherhood and other Islamist organizations from Syria, which resulted in the slaughter of thousands of civilians in what is more commonly known as the Hama Massacre, and an additional 17,000 people disappeared without trial during his reign, according to Human Rights Watch. ${ }^{83}$ Both Hafez Al-Assad and Bashar Al-Assad were/are members of the Ba'ath Party of Syria, which adheres to an Arab nationalist and Arab socialist ideology that is at odds with religious organizations and proponents of imperialism. After the Hama Massacre, Hafez Al-Assad's regime began indiscriminately targeting civilians perceived as being members of Islamist organizations or threats to the Assad government through the use of the mukhabarat, essentially secret police, and military attacks, tactics that are still used under Bashar Al-Assad. ${ }^{84}$ Assad was able to get away with these human rights violations because Syria was essentially under a blackout during his reign where all forms of media and assembly were censored and restricted and independent media outlets were prohibited. ${ }^{85}$ Syrians were hopeful that Bashar Al-Assad would be more democratic in comparison to his predecessor; however, he has merely been an extension of his father and has since lived up to Hafez Al-Assad's infamous legacy.

The ongoing conflict in Syria can be traced back to Hafez Al-Assad's policies. Syrians have been subject to oppression at the hands of the Assad family and the Baath Party for over

\footnotetext{
${ }^{82}$ Khaled Yacoub Oweis, “Syria's Assad vows to life emergency law by next week," Reuters, April 16, 2011, https://www.reuters.com/article/us-syria/syrias-assad-vows-to-lift-emergency-law-by-next-weekidUSTRE72N2MC20110416

83 “A Wasted Decade: Human Rights in Syria during Bashar al-Asad's First Ten Years," Human Rights Watch, July 16, 2010, https://www.hrw.org/report/2010/07/16/wasted-decade/human-rights-syria-during-bashar-al-asads-firstten-years-power\#

${ }^{84}$ Ibid.,

${ }^{85}$ Radwan Ziadeh, "Countries at the Crossroads 2011- Syria," refworld, November 10, 2011, https://www.refworld.org/docid/4ecba6432b.html
} 
half a century and seized the opportunity to revolt during the Arab Spring. The Syrian conflict is not only the result of a civil war against a corrupt government and a series of overlapping proxy wars, it is also the result of a deeply divided and fractured Syrian population. Protests and chants gradually changed from calls for freedom and democracy to racist and religious slurs, "screaming in the mosques to kill Alawites and Shias... Christians go to Beirut, Alawites go to your coffins." 86 Since the conflict has pitted Alawites, Sunnis, Shias, Christians, and sectarians against each other, it will ultimately hinder any attempts of peacebuilding in the future since the Syrian population no longer trusts the government or rebels, but also distrusts itself. The events unfolding in Syria have become a "war first and a sectarian conflict second." ${ }^{87}$ Confusion on who supports what and who adheres to which ideology has ultimately led to indiscriminate killing from both pro-Assad loyalists and anti-Assad rebels, and appears to have impacted U.S. foreign policy and military action within the region.

\section{U.S. Involvement in Syria \& Theoretical Relevance}

The United States attempted to minimize its role in Syria when the conflict began by first attempting to economically coerce the Assad government through the use of sanctions and by publicly condemning Assad's actions. However, United States-Syrian relations were tenuous at best before the onset of the war and have been non-existent since 2012. The United States had already imposed a series of economic sanctions on Syria and listed the country as a state sponsor of terrorism before the Syrian conflict, so additional sanctions imposed by the United States had little effect. While there was a network tie between the two countries, or nodes, going into the

\footnotetext{
${ }^{86}$ Tracey Shelton, "Fighting in Syria shifts as sectarian divisions intensify," PRI, June 12, 2013, https://www.pri.org/stories/2013-06-12/fighting-syria-shifts-sectarian-divisions-intensify

${ }^{87}$ Max Fisher, "The one map that shows why Syria is so complicated," The Washington Post, August 27, 2013, https:/www.washingtonpost.com/news/worldviews/wp/2013/08/27/the-one-map-that-shows-why-syria-is-socomplicated/?utm_term $=.39 \mathrm{c} 4$ eaa $92 \mathrm{bc5}$
} 
conflict, the tie was the absence of diplomatic relations. The absence of such relations is in itself a tie guiding the behavior of the two countries because it still influences behavior and helps form a network hierarchy within the conflict. However, this absence of diplomatic relations due to the ill feelings between the two countries may explain why the United States was not overtly eager to show any sign of lenience to the Assad government, and in turn, may have contributed to their decision to help Syrian and Kurdish rebels. Similarly, the absence of such diplomatic relations impacted how the United States transmitted information to Syria at the onset of the civil war, as well as throughout the conflict, especially with regards to terrorist insurgencies. The United States has paid a priced for its lack of intelligence sharing with the Syrian government regarding al-Qaeda, ISIS, and other security matters ${ }^{88}$ The reluctance to share important information before and during the conflict has allowed for the twofold war, the Syrian civil war and the War on Terror, to spiral out of control.

As the conflict unfolded, the United States decided to side with the enemy of their enemy as a strategic move to hinder Assad and the Syrian government. In early 2013 under the Obama Administration, Congress authorized the State Department to provide the Free Syrian Army with nonlethal foreign assistance in accordance with preexisting provisions of law, particularly regarding terrorism-related sanctions. ${ }^{89}$ However, nonlethal assistance was short-lived after U.S. shipments to anti-Assad rebels were intercepted by the Islamic Front, an Islamist organization seeking to overthrow Syrian President Bashar Al Assad and implement an Islamic state in Syria. ${ }^{90}$ Since terrorist organizations, namely the Islamic Front and later Al-Nusra and ISIS, were

\footnotetext{
${ }^{88}$ Joshua Landis, "The U.S.-Syria Relationship: A Few Questions," Middle East Policy Council, vol. 17(3), Fall 2010, https://www.mepc.org/us-syria-relationship-few-questions

${ }^{89}$ Carla E. Humund, Christopher M. Blanchard, Mary Beth D. Nikitin, "Armed Conflict in Syria: Overview and U.S. Response," Congressional Research Service, January 2, 2019, 39, https://fas.org/sgp/crs/mideast/RL33487.pdf ${ }^{90}$ Mark Landler, "U.S. Considers Resuming Nonlethal Aid to Syrian Opposition," The New York Times, January 9, 2014, https://www.nytimes.com/2014/01/10/world/middleeast/syria-aid-may-resume-despite-fears-over-where-itwill-go.html
} 
able to intercept nodes' transmission of goods and information, the United States had to change the ties in which they chose to transmit resources and intelligence. Shortly before this happened, President Obama directed the CIA to start a covert program known as Timber Sycamore to train and equip Syrian rebels via special intelligence, training programs with local allies, particularly Jordan and Turkey who served as intermediaries, and cash transfers. ${ }^{91}$ Congress did not authorize the program until September 2014 when they agreed to begin sending American troops and support staff to the region to fight the War on Terror against ISIS. Troops were only authorized to train Syrian opposition forces against Assad and ISIS and were prohibited from entering into hostilities. ${ }^{92}$ According to Congress, the bill did not authorize the introduction of "United States Armed Forces into hostilities or into situations wherein hostilities are clearly indicated by the circumstances." ${ }^{93}$ However, the train and equip program faced some unforeseen obstacles and was ended by the Trump Administration in June 2017.

Before Trump ended the program, the United States inadvertently armed various terrorist organizations through their assistance to Syrian rebels, and U.S. troops may have gone as far as bussing ISIS fighters into government held regions of Syria to help topple Assad. Since the Syrian conflict has become a twofold war, the United States' decision to aid terrorists when it harms Assad and pro-government forces appears to be in line with the SNT principle of structural hierarchy. The United States has been hesitant to directly attack Assad's forces for a variety of reasons, including upsetting Russia and damaging the network structure, but appears to

\footnotetext{
${ }^{91}$ Mark Mazzetti \& Ali Younes, “C.I.A. Arms for Syrian Rebels Supplied Black Market, Official Says,” The New York Times, June 26, 2016, https://www.nytimes.com/2016/06/27/world/middleeast/cia-arms-for-syrian-rebelssupplied-black-market-officials-say.html

92 Ibrahim Hamidi, 'Syrian Opposition Fighters Withdraw from US ‘Train and Equip' Program, The Syrian Observer, June 22, 2015, https://syrianobserver.com/EN/news/29743/syrian_opposition_fighters_withdraw from_us_train_equip_program.html

$\overline{93}$ “H.J. Res. 124-Continuing Appropriations Resolution, 2015," Congress. Gov, September 19, 2014, https://www.congress.gov/bill/113th-congress/house-joint-resolution/124/text?overview=closed
} 
have chosen to use terrorist fighters as pawns to benefit the United States and its place in the Syrian conflict network while also hurting Assad. However, the decision to occasionally aid terrorists is selective and should be examined differently than the inadvertent arming of terrorist organizations. The interception of goods and information is associated with the SNT principle of ties between nodes serving as the transmission of goods and information within the network. When these resources were intercepted, it resulted in the restructuring of the network as the relations between the United States and other nodes that were seen as allies were damaged, and forced the United States to seek other channels.

In 2015, Col. Patrick Ryder, U.S. Central Command spokesperson, issued a statement saying, "On Sept. 21-22 they (New Syrian Forces coalition) gave up six pickup trucks and a portion of their ammunition to a suspected Al Nusra Front intermediary," a violation of train and equip guidelines in Syria. ${ }^{94}$ Al-Nusra Front, also known as Jabhat Fatah al-Sham, is a branch of Al-Qaeda fighting to implement an Islamic state in Syria. In addition, according to a study carried out by Conflict Armament Research (CAR), roughly 90 percent of ISIS weapons and 87 percent of their ammunition are Warsaw Pact calibers that had been purchased by the United States and Saudi Arabia and were part of an unauthorized retransfer to Syrian opposition forces, which violated the agreement of sale with the original supplier governments from various EU member states. ${ }^{95}$ The approximate time it took for weapons to be manufactured by an EU member state, sold to Saudi Arabia or the United States, provided to anti-Assad rebels in Syria, and then transferred to ISIS fighters in Iraq took less than two months, according to CAR field

\footnotetext{
${ }^{94}$ Jim Miklaszewski and Courtney Kube, "U.S. Admits Syrian Rebels Gave Trucks, Ammo to Al Qaeda-Linked Group," NBC News, September 22, 2015, https://www.nbcnews.com/news/world/u-s-admits-syrian-rebels-gaveweapons-al-qaeda-linked-n434096

95 "Weapons of the Islamic State: A three year investigation in Iraq and Syria," Conflict Armament Research, December 2017, 5.
} 
investigations. ${ }^{96}$ Due to the unauthorized transfers, ISIS obtained anti-armor warheads, including an anti-tank missile launcher, which poses a significant threat to anti-ISIL coalition troops. While the arming of ISIS fighters appears to have been unintentional, it is a prime example of how nodes' behavior and decisions directly affect other nodes within a given network, even if it is not immediately obvious. The United States' decision to arm rebels had a domino effect in which terrorists benefited and the War on Terror may have been prolonged.

As previously mentioned, in addition to providing arms and ammunition to various terrorist organizations, it has also been alleged that the United States approved a deal with Syrian Democratic Forces (SDF) in 2017 to bus thousands of ISIS fighters and their families out of Raqqa to Deir al-Zor, where Assad troops were gaining ground. According to Talal Silo, a former commander in SDF, an "Agreement was reached for the terrorists to leave, about 4,000 people, them and their families," with roughly 3,500 of them being fighters. ${ }^{97}$ Silo referred to the operation as 'theater' because the SDF was ordered to ban people from entering Raqqa as a way to cover up those that were bussed out, a move the United States refutes. However, this was a move that further angered Turkey since Deir al-Zor is in eastern Syria near the Turkish border, and not only would such a move put Turkey at risk of future ISIS infiltration, but it also increases the presence of Kurdish rebels in the region. Turkey and the United States have had strained relations throughout the conflict due to U.S. support of Kurdish rebels that are part of the Kurdish People's Protection Units (YPG). Turkey alleges that the YPG is affiliated with the Kurdistan Worker's Party (PKK) and does not see a distinction between the two groups. Both the United States and Turkey recognize the PKK as a terrorist organization, which has strained U.S.-

\footnotetext{
96 Ibid., 6.

${ }^{97}$ Dominic Evans \& Orhan Coskun, "Defector says thousands of Islamic State Fighters left Raqqa in secret deal," Reuters, December 7, 2017, https:/www.reuters.com/article/us-mideast-crisis-syria-defector/defector-saysthousands-of-islamic-state-fighters-left-raqqa-in-secret-deal-idUSKBN1E12AP
} 
Turkish relations since the U.S. continues to arm and train Kurdish rebels in Syria despite Turkey's disapproval. This has resulted in infighting between Turkey and the United States even though both countries claim to be fighting against Assad and ISIS. The United States' decision to arm Kurdish rebels that may or may not be terrorists may also be explained by SNT. By using Kurdish rebels as stand-ins for American forces, the United States has shaped the structural hierarchy within the network in its favor. The decision increases the power of Kurds in not only Syria but the region as a whole as they are seen as allies of the United States, limits Turkish control since U.S.-Turkish relations have been on the rocks as of late, and allows for Kurds to enter into military hostilities that the United States is legally prevented from joining and shifts responsibility away from the U.S. and onto the rebels.

However, American foreign policy in Syria is constantly changing, presumably due to the large number of countries and organizations involved in the conflict, in addition to the contentious legality of international involvement. As more actors enter into the Syrian conflict network, the structural hierarchy is continuously in a state of flux and nodes' behavior are altered. Since the Syrian conflict began in 2011, Congress and both administrations have debated whether or not the president has the authority to begin conducting U.S. military operations in Syria without a declaration of war. The United Nations Security Council (UNSC) has been unable to pass a resolution that would legally allow international military intervention in Syria. ${ }^{98}$ According to UN Secretary General Ban Ki-moon, there are two exceptions to the UN prohibition on the use of force; the first is when force is necessary for the restoration of international peace. Ban has stated that "Russia and China have blocked every attempt of the

\footnotetext{
${ }^{98}$ Pnina Sharvit Baruch \& Brandon Weinstock, "Military Intervention in Syria: Is It Legal?" The Institute for National Security Studies, September 11, 2013, http://www.inss.org.il/publication/military-intervention-syria-legal/
} 
UNSC to authorize the use of force against Syria, rendering this exception unavailable." 99 Russia has used its position in the Syrian conflict network as well the UNSC network to benefit its interests, which have in turn directly affected the Syrian conflict. Russia is ranked high in the Syrian conflict hierarchy as one of Syria's main supporters, as well as the UNSC hierarchy as they are a permanent member of the council. Russia and China's actions at the Security Council created a domino effect within the Syrian conflict. Their decision shaped the international community's ability to legally involve themselves in the fighting and has allowed for a civil war to spiral out of control into a regional war. The second exception to the use of force is when it is used in self-defense; however, the U.S. and its allies have not been directly attacked. Even though the Security Council was unable to pass resolutions regarding military involvement, they did unanimously adopt Resolution 2254 in 2015, which demanded a ceasefire in Syria and called for the creation of a political settlement. Neither of these goals have been achieved in the four years since the passage of UNSCR 2254, but the Resolution was vital to the subsequent Astana and Geneva peace talks.

Absent a legal basis for international intervention in Syria, NATO has been adamant about upholding UNSCR 2254 and the Geneva process, and has repeatedly restated their commitment to the Coalition to Defeat ISIS/Da'esh, which is dedicated to fighting terrorism and securing stability in the region. Even though there is no legal ground for international action in Syria, the U.S., France, and the UK have taken joint military action in Syria on numerous occasions, most notably after the Syrian government's use of chemical weapons on civilians. Assad's use of chemical weapons is a flagrant violation of the Geneva Protocol, the Treaty of the Non-Proliferation of Nuclear Weapons, the Chemical Weapons Convention, and numerous

\footnotetext{
${ }^{99}$ Ibid.
} 
UNSCR resolutions. Due to this, NATO has justified their actions in Syria by stating that the organization "considers any use of chemical weapons by State or non-State actors to be a threat to international peace and security." ${ }^{100}$ NATO member states have created their own justifications and legal bases for actions in Syria according to their independent domestic laws. In order to justify U.S. involvement in Syria, President Obama asserted that the War on Terror against ISIS in Syria and Iraq was in accordance with US law under the Authorization for Use of Military Force Against Iraq Resolution of 2002 because ISIS is an offshoot of Al-Qaeda and the United States has the authority to defend Iraq from both Islamist organizations. ${ }^{101}$ In this instance, the United States' relations with Al-Qaeda, or the lack thereof, allowed for the United States to somewhat legally involve themselves in Syria. Past relations with the terrorist organization continued to impact American decision making in Syria in accordance with SNT Principle 1. However, this authorization of the use of force does not apply to the use of military force against Assad. Retaliatory airstrikes against Assad by the United States and its allies violates international law, yet they have received little criticism, most likely because of the severity of Assad's actions.

Human rights violations have gotten progressively worse over the course of the conflict, but it appears that international altruism is hardening and humanitarian efforts are dwindling. The international community is no longer appalled by the Syrian conflict, rather, they have become accustomed to the ongoing atrocities. Activists in the United States brought a Syrian regime defector code-named Caesar to testify before Congress about his firsthand experiences of torture and starvation in Syrian prisons. According to the Syrian Network for Human Rights,

\footnotetext{
100 "Statement by the North Atlantic Council on Actions taken against the use of chemical weapons in Syria," North Atlantic Treaty Organization, April 14, 2018, https://www.nato.int/cps/en/natohq/news153670.htm

${ }^{101}$ Carla E. Humund, Christopher M. Blanchard, Mary Beth D. Nikitin, "Armed Conflict in Syria: Overview and U.S. Response," Congressional Research Service, January 2, 2019, 33, https://fas.org/sgp/crs/mideast/RL33487.pdf
} 
more than 117,000 people in Syria have been arrested and detained since March 2011, including an American citizen and humanitarian activist named Layla Shweikani that was executed by Assad's government. ${ }^{102}$ Due to Caesar's testimony, the United States Congress has attempted to pass the Caesar Syria Civilian Protection Act, which would impose new sanctions on entities working with Assad and would lay the groundwork for a no-fly zone in Syria. However, the Act is still a draft since it was passed by the House in 2016, but has not yet been approved by the Senate or the President, and no action has been taken on behalf of Ms. Shweikanki. Top politicians' feelings towards the conflict have been far from consistent with most adhering to party lines, often gridlocked when it is time to vote on policy regarding Syria. ${ }^{103}$

Former Secretary of State John Kerry was a big proponent of intervention in Syria based on altruistic means. In a speech in 2013, Kerry noted that the United States is war-weary after more than a decade of conflict, and that he is too, but that that does not mean the United States can shirk their international responsibility by simply hoping for peace instead of taking appropriate action. Kerry went on to state, "history would judge us all extraordinarily harshly if we turned a blind eye to a dictator's wanton use of weapons of mass destruction against all warnings, against all common understanding of decency." 104 President Obama echoed Secretary Kerry's sentiment the following day when he announced he would be asking Congress to authorize the use of force in Syria, but that it would not be an open-ended intervention involving boots on the ground. Obama referred to Assad's chemical attack on civilians, which was a flagrant violation of Obama's self-imposed redline, as "an assault on human dignity. It also

\footnotetext{
102 "Syria: Stories Behind Photos of Killed Detainees," Human Rights Watch, December 16, 2015, https://www.hrw.org/news/2015/12/16/syria-stories-behind-photos-killed-detainees

${ }^{103}$ Alicia, Parlapiano, Anjali Singhvi, Jon Huang, \& Thomas Kaplan, "Where Top Lawmakers Stand on Syria: Now and in 2013," The New York Times, April 7, 2017, https://www.nytimes.com/interactive/2017/04/07/us/politics/congress-quotes-on-syria-airstrikes.html ${ }^{104}$ Peter Baker \& Michael R. Gordon, "Kerry Becomes Chief Advocate for U.S. Attack," The New York Times, August 30, 2013, https://www.nytimes.com/2013/08/31/world/middleeast/john-kerry-syria.html
} 
presents a serious danger to our national security." ${ }^{105}$ Kerry's successor, Rex Tillerson, had more of an ambiguous approach. By this time, U.S. involvement in Syria was more so due to the War on Terror and ISIS than it was because of Assad. Tillerson wanted to turn to more diplomatic measures to handle the conflict, but was not ready to withdraw troops from the region. Tillerson stated, "We cannot repeat the mistake of 2011," alluding to Obama's withdrawal of troops from Iraq, which many critics argue created further instability in the country and allowed ISIS to morph out of Al-Qaeda. ${ }^{106}$ Tillerson's sentiment was echoed by CENTCOM Commander Gen. Votel who stated, "after we have removed [ISIS] from their control of the terrain... we have to ensure that the right security and stability is in place so that they cannot resurge."107 Two months after Tillerson's statements on keeping boots on the ground, President Trump fired him and buckled down on his stance that troops in Syria would be "coming out of Syria, like, very soon." 108 President Trump's statement has not been expanded upon, so it remains unclear as to when U.S. troops will be withdrawn from Syria.

Tillerson's successor, Mike Pompeo, appears to echo his sentiments that the United States will not withdraw from Syria until the War on Terror is over. In an announcement in January 2019 to U.S. allies, Pompeo stated, “America will not retreat until the terror fight is over. We will labor tirelessly alongside you to defeat ISIS, Al-Qaeda and other jihadists."109

\footnotetext{
105 "Barack Obama statement on US intervention in Syria - full text," The Guardian, August 31, 2013, https://www.theguardian.com/world/2013/aug/31/barack-obama-statement-us-intervention-syria

106 Tracy Wilkinson, "Tillerson says U.S. military should stay in Syria and vows diplomatic push to end civil war," January 17, 2018, https://www.latimes.com/nation/la-fg-tillerson-syria-20180117-story.html 107 "27 Feb 18: House Armed Services Committee Hearing on Terrorism and Iran FULL TRANSCRIPT," U.S.

Central Command, February 27, 2018, http://www.centcom.mil/MEDIA/TRANSCRIPTS/Votel-HASC-Testimony27-FEB-2018/

108 “'Trump says we're leaving Syria, 'like, very soon.' Bad idea," The Washington Post, March 31, 2018, https://www.washingtonpost.com/opinions/global-opinions/trump-says-were-leaving-syria-like-very-soon-badidea/2018/03/31/e50bb7aa-3434-11e8-94fa-32d48460b955 story.html

109 "US to expel every las Iranian boot from Syria - Pomepo," British Broadcasting Corporation, January 10, 2019, https://www.bbc.com/news/world-middle-east-46828810
} 
However, Pompeo went a step further by stating that the United States will also be working with its allies to "expel every last Iranian boot" from Syria, a comment in clear contradiction of a statement made by President Trump the week before. ${ }^{110}$ At the beginning of January 2019, Trump said Iran "can do what they want" in Syria when discussing the withdrawal of US troops from the region even though the removal of Iran and its influence over Syria has been a top concern, especially due to the ongoing proxy war with Iran and Israel. ${ }^{111}$ Pompeo, on behalf of the Trump Administration, announced a three-part strategy regarding Syria at the $36^{\text {th }}$ Annual Jewish Institute for National Security of America Awards Dinner in October 2018. He claimed the three-part strategy will focus on the defeat of ISIS, the implementation of a political settlement in Syria in accordance with UNSCR 2254, and the expulsion of Iranian forces from Syria. ${ }^{112}$ Pompeo's statement has been similarly restated on multiple occasions by National Security Advisor John Bolton, Ambassador James Jeffrey, the new Secretary of State's Special Representative for Syria Engagement, and former Special Presidential Envoy for the Global Coalition to Defeat ISIS Brett McGurk. Trump has made multiple public statements that appear to be in direct contradiction with ongoing policy in Syria, which has resulted in the resignation of Defense Secretary Mattis and Special Presidential Envoy McGurk. Both Mattis and McGurk have repeatedly spoken against the removal of troops from Syria as it will create a vacuum that will not only harm allies in the region, but will allow for a resurgence of ISIS and other terrorist organizations as clandestine cells still exist.

\footnotetext{
110 Ibid.,

111 Amir Tibon, “Iran 'Can Do What They Want' in Syria, Trump Says,” Haaretz, January 3, 2019, https://www.haaretz.com/middle-east-news/iran/iran-can-do-what-they-want-in-syria-trump-says-1.6805949

112 "Remarks at the 36th Annual Jewish Institute for National Security of America Awards Dinner," U.S. Department of State, October 10, 2018, https:/www.state.gov/secretary/remarks/2018/10/286559.htm
} 
On December 19, 2018, Trump tweeted "We have defeated ISIS in Syria, my only reason for being there during the Trump Presidency," and then later that day posted a video stating, "We have won against ISIS;" however, he moderately walked back his statements in another tweet posted December 23, 2018 in which he claimed "ISIS is largely defeated," acknowledging that the fight against the terrorist organization is still ongoing. ${ }^{113}$ Yet on January 16, 2019 Vice President Mike Pence announced "ISIS is defeated" hours after an ISIS suicide bomber killed two American soldiers, a civilian DIA worker, and an American contractor, along with fifteen others in Manbij. ${ }^{114}$ Trump's refusal to walk back his statements on the defeat of ISIS and his incessant commitment to bringing troops home immediately has created a divide among politicians.

Sen. Lindsey Graham, a longtime supporter of Trump, argued that Trump's statements emboldened ISIS and led to the events on January $16^{\text {th }}$. Graham claims the statements by Trump "set in motion enthusiasm by the enemy we're fighting... every American wants our troops to come home, but I think all of us want to sure that when they do come home, we're safe."115 The lack of agreement between Trump, his advisors, and high-ranking politicians has caused a lot of confusion regarding ongoing policy and whether or not troops will be removed. Months after Trump initially claimed ISIS was defeated, a U.S.-backed alliance made up of Syrian fighters declared the demise of the physical ISIS caliphate in Syria. However, the alleged defeat of the caliphate does not mean that terrorist cells are no longer present in the country. The head of the U.S. military's CENTMOM, Gen. Votel, may have been successful in persuading Pres. Trump to

\footnotetext{
113 Aaron Rupar, “Trump can't decide if the US has defeated ISIS,” Vox, January 7, 2019, https:/www.vox.com/policy-and-politics/2019/1/7/18172063/trump-isis-comment-incoherent

114 Eric Schmitt, Ben Hubbard, \& Rukmini Callimachi, "ISIS Attack in Syria Kills 4 Americans, Raising New Worries About Troop Withdrawal," The New York Times, January 16, 2019, https://www.nytimes.com/2019/01/16/world/middleeast/isis-attack-syria-troops.html

115 Zachary Cohen, "Lindsey Graham says Trump's Syria statements emboldened ISIS,” CNN, January 16, 2019, https://www.cnn.com/2019/01/16/politics/graham-syria-attack-trump/index.html
} 
reconsider the immediate and total withdrawal of troops from Syria by highlighting the importance of maintaining "a vigilant offensive against the now largely dispersed... [IS] that retains leaders, fighters, facilitators, resources and the profane ideology that fuels their efforts." ${ }^{16}$ Even though ISIS has suffered substantial losses, the UN Secretary General believes that there could still be as many as 35,000 ISIS fighters in Iraq and Syria. ${ }^{117}$

Despite warnings from top security officials on the repercussions of pulling out troops too soon, many politicians and Americans appear to be in favor of the move. The American public has consistently opposed any form of U.S. involvement in the Syrian conflict since its onset in 2011. A Pew Research poll on public support for U.S. involvement at the end of 2012 when the United States was still trying to minimize any potential involvement found that only 27 percent of Americans felt the United States has a responsibility to act in Syria; however, this number grew to 45 percent in the middle of 2013 when Americans were asked if the United States should intervene in the event of Assad or the Syrian government using chemical weapons on civilians. ${ }^{118}$ Gallup polled Americans on public support for missile airstrikes and military intervention in Syria in April of 2018 and Americans were still sharply divided. Of those polled, 50 percent approved of military action while 43 percent disapproved and 7 percent had no opinion. ${ }^{119}$ While this is an increase from the 2012-2013 polls, it is still remarkably low in comparison to support for past military action, with the exception of Libya. Support for action in Iraq in 2003 was at 76 percent compared to Afghanistan in 2001 which was 90 percent; support

\footnotetext{
116 "IS 'caliphate' defeated but jihadist group remains a threat," British Broadcasting Corporation, March 23, 2019, https://www.bbc.com/news/world-middle-east-45547595

${ }^{117}$ Ibid.,

${ }^{118}$ Carroll Doherty, "Possible chemical weapons use by Syria has influenced public support for action in past polls," Pew Research Center, August 22, 2013, http://www.pewresearch.org/fact-tank/2013/08/22/possible-chemicalweapons-use-by-syria-has-influenced-public-support-for-action-in-past-polls/

${ }^{119}$ RJ Reinhart, "Snapshot: Half of Americans Approve of Strikes on Syria," Gallup, April 24, 2018, https://news.gallup.com/poll/232997/snapshot-half-americans-approve-strikes-syria.aspx
} 
for military action in Libya in 2011 was the lowest with only 47 percent of Americans supporting any form of action. ${ }^{120}$ Similarly, 60 percent of Americans opposed accepting Syrian refugees in 2015, a time in which Congress passed legislation banning the admittance of Syrian and Iraqi refugees. ${ }^{121}$ The Trump Administration implemented a travel ban on seven countries: Iran, Libya, Somalia, Syria, Yemen, North Korea, and Venezuela. Chad, Iraq, and Sudan were removed from the list in January 2017. However, in a February 2018 poll, 56 percent of Americans felt the U.S. has a responsibility to accept refugees, but the poll was about refugees as a whole and not just refugees fleeing the Syrian conflict. ${ }^{122}$ The unwillingness to accept refugees appears to show not only a feeling of a lack of responsibility for the Syrian consequences that stem from the conflict, but also a lack of altruism that may have ultimately hindered U.S. involvement in Syria.

Since the Libyan and Syrian conflicts ran parallel to one another for a period of time, it is plausible that intervention in Libya hindered involvement in Syria as well. The U.S. was still involved in Iraq and Afghanistan and could not handle four ongoing interventions at once; however, it appears that the Iraq intervention may have stunted involvement in both conflicts. The U.S. attempted to pull out of both Iraq and Libya while the Syrian civil war was becoming a regional conflict, and the withdrawal of troops in both instances led to a vacuum in which terrorist organizations were able to gain traction and spread across the Middle East and Northern Africa. Actions taken by both the Obama and Trump Administrations that were intended to separate them from the actions of their predecessors resulted in worsening situations without

\footnotetext{
120 Ibid.,

${ }^{121}$ Jeffrey M. Jones, “Americans Again Opposed to Taking In Refugees,” Gallup, November 23, 2015 , https://news.gallup.com/poll/186866/americans-again-opposed-taking-refugees.aspx

${ }^{122}$ Hannah Hartig, "Republicans turn more negative toward refugees as number admitted to U.S. plummets," Pew Research Center, May 24, 2018, http://www.pewresearch.org/fact-tank/2018/05/24/republicans-turn-more-negativetoward-refugees-as-number-admitted-to-u-s-plummets/
} 
clear-cut solutions. However, the unwillingness to provide humanitarian aid to parts of Syria that are under government control and the unwillingness to accept refugees fleeing violence that the United States has played a role in paints an even more confusing picture as to what the goals of the Syrian conflict truly are, and when humanitarian concerns will become a priority.

In addition, the lasting effects of these interventions seem to enforce the principles of SNT. While the Libyan and Syrian conflicts included a number of different actors, quite a few nodes higher up within both conflict hierarchies appear to overlap. The decisions made by these nodes in Libya carried over to the Syrian conflict and influenced their behavior. This statement is not implying that the actions taken in Libya directly affected the actions taken in Syria, rather, it may be argued that because nodes within a given network are mutually dependent their past actions helped determine their future decisions. The fact that there were overlapping actors in each conflict helps contribute to the influential relationships between nodes, how the ties between the nodes allowed them to transmit goods and information, and how those ties shaped the network hierarchy. Relations aside, the involvement of these nodes in both conflicts also shaped their policy decisions as concurrent military operations would have greatly impacted budgets, military capability, and how each node views the region. The forging or severing of relations between nodes in Libya would have also have impacted the level of involvement nodes chose to take in Syria. 


\section{CHAPTER VI: ANALYSIS}

To better understand U.S. foreign policy in Syria and the criteria for humanitarian intervention, the Syrian case study and the four necessary factors from the Libyan example will be placed within the theoretical framework of social network theory. The main principles from social network theory that will be used in this analysis are: nodes are mutually dependent and influence each other's behavior; ties between nodes serve as channels for the transmission of goods and information within networks; ties within a given network have the ability to create structures which may influence nodes' behavior. ${ }^{123}$ By analyzing U.S. foreign policy, the decision to intervene, and relations with other nodes within the Libyan conflict and then comparing the analysis to the same criteria within the Syrian conflict, a decision might be made as to whether or not intervention is possible and what is actually driving U.S. decision-making. The three principles of social network theory will be applied to both conflicts and then an analysis will be conducted in order to address the prevalence of Mikael Blomdahl's four criteria for intervention in the Syrian case study.

\section{Humanitarian Intervention in Libya}

SNT Principle 1: Nodes are mutually dependent and influence each other's behavior.

The main nodes within the Libyan conflict were the Libyan Arab Jamahiriya (proGaddafi forces), NATO member states (particularly the United States, the United Kingdom, France, Turkey, and Italy), and anti-Gaddafi forces. The United States' decision-making in Libya was heavily guided by the involvement of the other aforementioned nodes, and vice versa. The United Kingdom and France were the initial ringleaders with regards to pushing for humanitarian involvement in Libya and were the two most adamant proponents of UNSC Res. 1973 that

\footnotetext{
${ }^{123}$ Lieke ‘t Gilde, "Social Network Theory in International Relations Research,” January 2014, 7-8, http://arno.uvt.nl/show.cgi?fid=133127
} 
granted an international legal basis for military intervention. Then-British Prime Minister David Cameron claimed that military action in Libya against Gaddafi's regime was "necessary, it is legal and it is right," while then-French President Nicolas Sarkozy argued, "If we intervene on the side of the Arab nations it is because of a universal conscience that cannot tolerate such crimes." ${ }^{24}$ However, their actions were not guided solely by altruism and may be attributed to a variety of reasons, namely 'new' security challenges: energy security and migration. ${ }^{125}$

For the United Kingdom, their guiding interest appears to have been energy and protecting economic relations. British Petroleum (BP) signed \$1 billion deal with Libya in 2007 that allowed the drilling of both onshore and offshore wells. By 2009, oil production had not yet started, so BP upped their commitment to creating wells in Libya by stating that they would invest $\$ 20$ billion in Libyan oil production over the next 20 years. ${ }^{126}$ However, their push for oil production became increasingly more urgent after BP lost a combined $\$ 37.7$ billion in 2010 after the Macondo well disaster in the Gulf of Mexico, which had the potential to result in an additional $\$ 60$ billion in damage estimates. ${ }^{127}$ Despite the previous deals and commitments between London and Tripoli, oil production had not yet started by the time the first Libyan civil war broke out. Overthrowing Gaddafi and ending the war would have been beneficial to London oil production, and appears to have been vital to preserving the world oil market and protecting OPEC member states from the violence in Libya. However, economic relations were not the sole motive for intervention. While the United Kingdom did intervene on the premise of altruism and

\footnotetext{
${ }^{124}$ Michael Elliott, "Viewpoint: How Libya Because a French and British War," Time, March 19, 2011, content.time.com/time/world/article/0,8599,2060412,00.html

${ }^{125}$ Ruth Hanau Santini \& Arturo Varvelli, "The Libyan Crisis Seen from European Capitals," Brookings, June 1, 2011, https://www.brookings.edu/research/the-libyan-crisis-seen-from-european-capitals/

126 "France, U.K. Have differing Motives for Intervening in Libya, “Forbes, March 29, 2011, https://www.forbes.com/sites/energysource/2011/03/29/france-u-k-have-differing-motives-for-intervening-inlibya/\#1a02deeb5ad5

${ }^{127}$ Ibid.,
} 
the responsibility to protect, border security and the potential influx of a massive flow of refugees from Libya and the surrounding region played a vital role in their decision to intervene. During the Libyan conflict, the UK was cracking down on border control and national security to reduce immigration numbers. According to a UK Border Agency spokesperson, the Agency implemented new, tough measures in order to control the flow of immigrants from outside Europe, "this government has committed to reducing net migration from hundreds of thousands to tens of thousands." ${ }^{128}$ Despite these attempts, the UK experienced an 11 per cent increase in asylum applications, excluding dependents, in the first quarter of 2011 during the onset of the Libyan conflict. ${ }^{129}$ World instability contributed to the rise in asylum applications with Iranians making up the majority of applications to the UK in 2011; however, the civil unrest in Libya and subsequent war led to a "substantial increase in asylum applications from Libyan nationals in the period of January to September 2011." ${ }^{30}$ During the same timeframe in 2010, only 62 Libyan nationals applied for asylum in the UK whereas 672 applied in 2011, bumping Libya to second place behind Eritrea in African countries with the most nationals seeking refuge in the UK. ${ }^{131}$ France had similar concerns as those of the UK, which is why they formed their initial coalition together. Economic concerns were a driving factor for Sarkozy. The French oil company Total was producing 55,000 barrels of oil a day before the conflict broke out, accounting for roughly $2.3 \%$ of Libya's total production. ${ }^{132}$ However, Total's numbers were on the decline. They were

\footnotetext{
${ }^{128}$ Rebecca Drought, “UK Border controls - are they tough enough?” British Broadcasting Corporation, November 9, 2011, https://www.bbc.com/new/uk-15638607

129 "Control of Immigration: Quarterly Statistical Summary, United Kingdom," Home Office, 17, https://assets.publishing.service.gov.uk/government/uploads/system/uplods/attachment_date/file/116083/controlimmigration-q1-2011.pdf

130 "Immigration to the UK: the key facts," The Guardian, https://www.theguardian.com/news/datablog/2010/jun/26/non-eu-immigration-uk-statistics

${ }^{131}$ Ibid.,

${ }^{132}$ Libya Oil Almanac: An OpenOil Reference Guide, 126, openoil.net/wp/wp-content/uploads/2012/08/Libya-PDFv-2.0.pdf
} 
named the fifth largest publicly-traded international oil company in the world in 2009 and made up 3.2\% of Libya's oil production, but were experiencing a decrease in sales due to new OPEC quotas. ${ }^{133}$ By the time the Libyan civil war broke out in 2011, Total experienced a $12 \%$ drop in profit, down to $€ 2.7$ billion, during its First Quarter. ${ }^{134}$ In addition to oil, arms sales played an important role in the economic decision since France was the second largest arms supplier to Libya behind Italy with a total of $€ 210.15$ million in export licenses from 2005-2009. ${ }^{135}$ The European Union lifted its arms embargo in 2004 and Tripoli quickly became Paris' largest buyer, buying more than half a billion US dollars' worth of arms between 2004 and 2011. ${ }^{136}$ However, the Paris-Tripoli arms deal was at risk of being overtaken by Tripoli's growing relationship with Rome. Despite the large role economic reasons played in the intervention, they were not the only let alone the most important reason why France wanted to take immediate action against Gaddafi.

Before the Libyan conflict broke out, France had a large African Muslim population. The majority of African immigrants in France hail from Algeria and make up a population of roughly 600,000 people; however, there is also a sizable Tunisian minority population within the country that was less than pleased with the way France handled the Arab Spring revolution in Tunisia and the fall of Ben Ali. ${ }^{137}$ Sarkozy had a twofold job of walking a fine line to appease African immigrants in France, as well as French citizens that were upset about African Muslim immigration to France. The Libyan conflict broke out right before the 2012 French election and

\footnotetext{
133 Ibid.,

134 Ibid.,

135 "EU arms exports to Libya: who armed Gaddafi?" The Guardian, March 2, 2011, https://www.theguardian.com/news/datablog/2011/mar/01/eu-arms-exports-to-libya

136 "France, U.K. Have differing Motives for Intervening in Libya, “ Forbes, March 29, 2011 , https:/www.forbes.com/sites/energysource/2011/03/29/france-u-k-have-differing-motives-for-intervening-inlibya/\#1a02deeb5ad5

137 Ibid.,
} 
Sarkozy perceived his largest opponent to be Marine Le Pen, whose campaign appealed to voters that were dissatisfied with the incumbent's failure to address growing Muslim immigration. ${ }^{138} \mathrm{~A}$ growing population perceived African Muslim immigration as a threat to the secular French national identity, and it did not help that Gaddafi had threatened to "turn Europe black" with illegal immigrants from Africa just months before the onset of the Libyan civil war. ${ }^{139}$ Gaddafi doubled down on these claims again on March 6, 2011, less than two weeks before UNSC Res. 1973 was passed, by saying, “Thousands of people from Libya will invade Europe. There will be no-one to stop them anymore." ${ }^{\prime 140}$ Sarkozy's decision to intervene in Libya was not one borne solely out of economic reasons, but also out of domestic concerns regarding African immigration. From 1990-2009, France experienced an increase in foreign immigration by roughly one-third, with 41.1 per cent of immigrants coming from Africa, which was more than double the previous average of African immigrants. ${ }^{141}$

While altruism was a contributing factor to the UK and France's decision to form a coalition, it was ultimately not the deciding factor. The fear of an influx in illegal African immigration to Europe was a driving concern in their decision to form an intervention coalition, and is why they were able to garner the support of countries such as Italy and Turkey that are faced with similar issues that stem from violence and disarray across the Middle East and Africa. Since Italy is directly across the Mediterranean Sea from Libya, it has become the starting destination for African migrants. Italy was not previously known for hosting refugees, but this dramatically changed after the Arab Spring, which created a phenomenon referred to as the

\footnotetext{
${ }^{138}$ Soeren Kern, "Why France Was So Keen to Attack Libya," Gatestone Institute International Policy Council, March 23, 2011, https://www.gatestoneinstitute.org/1983/france-libya-attack

${ }^{139}$ Ibid.,

140 Ibid.,

141 "International Migration Report, 2011," United Nations Department of Economic and Social Affairs, December 2012, 33, 35, www.un.org/en/development//desa/population/migration/publications/migrationreport/docs/Migration Report2011.pdf
} 
North Africa Emergency. In 2011, Italy received 37,000 asylum requests; by 2016, this number grew exponentially with more than 181,000 requests in that year alone. ${ }^{142}$ Italy had been reluctant to intervene because of their close, colonial relationship with the Gaddafi regime and because of domestic political concerns regarding military intervention, but they had an aboutface when they began feeling the economic pressure that stemmed from halted oil production and the influx of refugees. Due to proximity and EU membership, Turkey was faced with a similar problem. However, Turkey was already preparing for an influx of Syrian refugees at this time due to the two conflicts running concurrently. ${ }^{143}$ Despite the Libyan conflict having strong regional effects, it quickly became an international war when NATO and North American forces began supporting military intervention.

Franco-British pressure resulted in American involvement and the imposition of a no-fly zone. The United States refused to support the coalition's no-fly zone if it lacked UN and international support and was still reluctant to join once support was offered. However, international support appears to have been one of the leading criteria necessary for U.S. intervention for multiple reasons. While the U.S. did not want to illegally start an intervention and wanted the support of its allies in the conflict, it also wanted to repay its allies for previous support in other international conflicts, namely Afghanistan. Secretary of State Clinton explicitly stated on March 27, 2011 in an interview with Meet the Press that the U.S. had asked NATO allies to invade Afghanistan a decade prior and that they offered their full support, so "When it comes to Libya, we started hearing from the U.K., France, Italy, and other of our NATO allies.

\footnotetext{
${ }^{142}$ Angelo Scotto, "From Emigration to Asylum Destination, Italy Navigates Shifting Migration Tides," Migration Policy Institute, August, 24, 2017, https://www.migrationpolicy.org/article/emigration-asylum-destination-italynavigates-shifting-migration-tides

${ }^{143}$ Liam Stack, "For Refugees From Syria, a Visit With No Expiration Date," The New York Times, November 14, 2011, https://www.nytimes.com/2011/11/15/world/middleeast/refugees-from-syria-settle-in-for-long-wait-inturkey.html
} 
This was in their vital national interests." ${ }^{144}$ While there were other contributing factors to United States' decision to intervene, the involvement of allies and their past relationship played an important role. If the UK and France had not helped the United States in Afghanistan, it is less plausible that the United States would have been likely to intervene in Libya on their behalf. The United States did intervene because of altruism and a desire for stability in the region, but that stability has a greater effect on America's European allies than it does on the United States. While the United States had similar concerns as their allies, more so on energy than national security due to ConocoPhillips business in Libya, they were of lesser concern. The decision hinged on the involvement of American allies and the concept of R2P. As NATO allies, the United States swore to protect fellow members from attack. Even though the Franco-British coalition initiated military action, retaliatory measures would have been sufficient grounds for U.S. involvement. In addition, the concept of R2P left actors involved in the conflict dependent upon each other. All member states at the UN endorsed the doctrine and therefore share the responsibility of enforcement as actors within the UN network. Military force is supposed to be used as a last resort with regards to R2P, and in the Libyan case it was. The Obama Administration, as well as the UK and French governments, called for the human rights abuses to end and for Gaddafi to step down. Gaddafi refused to protect his citizens, so the international community felt the need to step in.

SNT Principle 2: Ties between nodes serve as channels for the transmission of goods and information within networks.

Similar to that of Principle 1, actors within the Libyan conflict were constrained by their relationships/ties with other actors within the conflict network, so their decisions were not

144 "NBC's 'Meet the Press' interview with Secretary Gates and Secretary Clinton on Libya," U.S. Department of Defense, March 27, 2011, archive.defense.gov/transcripts/transcript.aspx?transcriptid=4801 
independent from one another. In addition, decisions made by actors within the network were more far-reaching than what meets the eye. While the United States was acting on its own behalf, its involvement was primarily concerned with the interests of its European allies, namely the UK, France, and Italy. Even though the United States may have not benefited directly from the Libyan intervention, they would have benefited indirectly from the protection and support of their allies. As members of NATO, they are sworn to protect each other in the event of an attack. As endorsers of R2P, they are sworn to uphold human rights and protections. Italy had been reluctant to join the coalition against Gaddafi because of their past relationship and ongoing ties; however, they sided with their European and Western allies when they realized Italian-Libyan relations were beyond repair and that they had other principles, such as R2P, to uphold, effectively severing their tie with Libya. Actors within the conflict were too interdependent upon each other, for a variety of reasons, to turn their back on calls for support, so the conflict became more complex as more actors became sucked into the conflict.

As the conflict grew, so did the network, essentially creating more ties. What started out as a Franco-British coalition, quickly turned into a NATO led intervention with support from the UN and the Arab League. However, the Libyan conflict was complex in the sense that it grew rapidly and ended quickly. Despite having dozens of involved actors between NATO, the Arab League, and Gaddafi supporters and protestors, most of the actors shared common interests and similar ties, therefore making intervention easier. While the list of belligerents was long, they were all siding with the rebels and anti-Gaddafi protestors against the Libyan Arab Jamahiriya. By sharing common interests, it made the transmission of goods and information easier. This is how UNSC Resolutions 1970 and 1973 were able to pass so quickly. Since the actors shared a number of ties, it made the transmission of aid and information between actors easier than in 
similar conflict networks. For example, at the time of the Libyan intervention and during the passage of the aforementioned resolutions, the members of the UN Security Council were China, France, Russia, the United Kingdom, the United States, Bosnia-Herzegovina, Brazil, Colombia, Germany, Gabon, India, Lebanon, Nigeria, Portugal, and South Africa. Of those members, all approved, except for abstentions by Brazil, China, Germany, India, and Russia. While some members, primarily China and Russia, had reservations about a no-fly zone and military intervention, they felt obligated to uphold UN principles, which is why they abstained instead of voting against the resolution, like they have in similar situations in which they have had more vested interests. ${ }^{145}$ The main proponents of intervention and members of the founding coalition were all permanent members of the Security Council, as well as NATO. While this would make sense since the UNSC passed the resolutions that formed the legal basis for intervention and NATO enforced their decision through military action, it made the transmission of information easier. As members of the same organizations, it forced these nodes into constant contact and knotted their ties together due to various overlapping of networks and interests.

In the years before the Arab Spring and the Libyan conflict, Tripoli attempted to repair its ties with a number of countries. For decades, Libya had been known as a state sponsor of terrorism by many Western countries, primarily the United States and members of the European Union because of attacks on embassies and Pan Am Flight 103. Washington repaired their relations with Tripoli in 2006 after 27 years of listing Libya as a state-sponsor of terrorism. ${ }^{146}$ Tripoli was also working on repairing relationships with the African Union, where Gaddafi eventually became chairman. However, Libya's closest relations crumbled as soon as conflict

\footnotetext{
145 "UN Security Council adopts resolution on Libya," Sputnik News, March 18, 2011, https://sputniknews.com/world/20110318163067336/

${ }^{146}$ Eric Lipton, "Libya Seeks Exemption for Its Debt to Victims," The New York Times, April 22, 2008, https://www.nytimes.com/2008/04/22/washington/22libya.html
} 
broke out because of other existing ties. Italy and France had been Libya's largest arms and ammunitions suppliers, but once the intervention began, the transmission of arms halted and ties were severed. Libya's allies in the African Union and Arab League became less supportive after the Arab Spring destabilized the region. Further disarray in Libya posed a threat to neighboring countries, which is why the Arab League was in favor of a no-fly zone and Western intervention, with the exception of Syria and Algeria, a stance they rarely hold. Of the fifteen states on the UN Security Council, two were observer states for the Arab League, Brazil and India, and one was a member of the League itself, Lebanon. The overlapping of states on the Security Council, NATO, and the Arab League helped with the transmission of information due to various working relations. In addition, these relations may have also constrained various decision-making processes.

The Arab League asked the Security Council to authorize a no-fly zone, not necessarily a military intervention. The League waffled at first due to false comments made by Gaddafi; however, they ultimately gave in to Western intervention as it was seen as the best worst-case scenario. According to researcher Mustafa Alani, a UAE scholar at the Gulf Research Center, "People might not like it but the only other option is to allow a civil war to develop in Libya... they don't like military intervention, but it in this case it is seen as the lesser evil." ${ }^{\text {4 }}$ "The foreign minister of Oman, Youssef bin Alawi bin Abdullah, appears to have concurred with this statement by stating, "If the Arab League does not take responsibility to prevent a downward spiral, that could lead to internal fighting or unwanted foreign intervention." 148 It also appeared that the Arab League was confident that the UNSC or EU would not take action if they did not

\footnotetext{
${ }^{147}$ M. Junaid Levesque-Alam, “Arab League Walks a Tightrope With Libya Intervention,” Foreign Policy in Focus, March 22, 2011, https://fpif.org/arab

148 “Arab states seek Libya no-fly zone," Al Jazeera, March 12, 2011, https://www.aljezeera.com/news/africa/2011/03/201131218852687848.html
} 
have the support of the League, which ultimately tipped the scales in favor of a no-fly zone and a subsequent military intervention. ${ }^{149}$ Previous Arab Spring uprisings were able to sort themselves out without international aid or intervention, but the protests in Libya were too great and the human rights violations too heinous to allow Libyan rebels to handle the civil war on their own. The Arab League was in favor of the rebels and recognized opposition forces as the legitimate National Libyan Council but sought international help in order to avoid further instability in the region. There were concerns expressed from the Arab League that international involvement would result in something similar to another Iraq invasion, but the consensus was that international involvement coupled with Arab League guidance would be the best decision to protect human rights in Libya.

For the same reason, United States was hesitant to get involved but intervened due to the actions of the UK and France. While the U.S. intervened because of the calls of U.S. allies, President Obama was not ready to send troops to Libya without first garnering the support of the Arab League since Washington had recently sanctioned an attack on a League member state: Iraq. ${ }^{150}$ Similarly, Italy was reluctant to abandon their relationship with Libya, but did so when the UK called on their European allies to assist them due to dwindling resources. These relations allowed for the transmission of information, but as well as resources and military capabilities. The ties between nodes within the Libyan conflict network, both good and bad, shaped how the subsequent intervention unfolded. The Arab League was able to work closely with the UN Security Council, as well as NATO, in order to provide intelligence information and military resources and humanitarian assistance. The overlapping of nodes within these organizations

\footnotetext{
149 Ibid.,

${ }^{150}$ Martin Chulov, "Arab League to reiterate backing for Libya no-fly zone," The Guardian, March 22, 2011, https:/www.theguardian.com/world/2011/mar/22/arab-league-libya-no-fly
} 
allowed for a faster transmission of information as these countries were involved in decisions on numerous fronts, therefore receiving more information as well as shaping the Libyan agenda, which may have contributed to the consensus of a no-fly zone from the Arab League, the UN Security Council, and NATO member states.

SNT Principle 3: Ties within a given network have the ability to create structures which may influence nodes' behavior.

Structures that have the potential to influence nodes' behavior are friendships between politicians, longstanding alliances, trade relations between countries, and membership of the same organizations. ${ }^{151}$ In the case of the Libyan conflict, alliances appear to have been the driving factor behind nodes' behavior. The United States intervened in Libya in part due to the influence of their allies, France and the United Kingdom. Even though the United States was starting to form a trade relationship with Tripoli with regards to oil and gas, the tie was not strong enough to withstand the centuries old Franco-British relationship. While networks are not inherently hierarchical, it does not mean that a hierarchy will not form. It is plausible that these structures will trump other ties in a given network, but that does not mean these structures are permanent or unmalleable. For example, Italy and Libya had a longstanding relationship since the Italian colonization of Libya a little over a century ago. In fact, close Italian-Libyan relations are why EU trade sanctions were lifted on Libya because of requests made by Italy. ${ }^{152}$ Despite having such close relations prior to the Arab Spring, they were not able to withstand the Libyan conflict. Italy was reluctantly forced to side with their European NATO allies. As a member of NATO, Italy swore to protect its fellow member states and to uphold the no-fly zone. In the case

\footnotetext{
151 "Social Network Analysis," Universiteit Van Amsterdam, 2.

152 "EU lifts Libya Sanctions," The Guardian, October 11, 2004, https:/www.theguardian.com/world/2004/oct/11/libya.eu
} 
of the Libyan conflict, NATO membership and the structural ties that stem from the organization are of more importance than trade relationships. In addition, past ties between politicians also proved to be influential in Libya, particularly with regards to France and presidents from other North African countries that were toppled by the Arab Spring.

President Sarkozy may have been eager to intervene in Libya due to his past relations with Gaddafi, Tunisian President Zine el-Abidine Ben Ali, and Egyptian President Hosni Mubarak, all of whom were deposed by the Arab Spring. Sarkozy had offered minimal support for the Arab Spring uprisings, which was met with disdain from the sizable African Muslim population in France. During the Tunisian uprisings, French Foreign Minister Michele AlliotMarie aided Ben Ali and vacationed in Tunisia at the time of revolts where she and her family negotiated a business deal with a close acquaintance of the Tunisian president. ${ }^{153}$ In order to save face, Sarkozy had to take a hardline stance against Gaddafi's regime. While this does not mean France would not have been willing to intervene in Libya had Sarkozy or the French government had different diplomatic relations in the past, it may be argued that those ties shaped the structure of the network in the Libyan conflict, effectively influencing Sarkozy and France's behavior. However, this behavior is not unique to the Libyan conflict. Countries with cozy relationships with dictators often attempt to save face by taking firm stances in subsequent conflicts. Similarly, the same may be said for countries notorious for attempting to topple dictators. While France was trying to overcome their history of non-interventionism, the United States was trying to distance themselves from their infamous reputation as interventionists. The United States has a long track record of military intervention, but President Obama and his Administration were

\footnotetext{
${ }^{153}$ France, U.K. Have differing Motives for Intervening in Libya, “ Forbes, March 29, 2011, https://www.forbes.com/sites/energysource/2011/03/29/france-u-k-have-differing-motives-for-intervening-inlibya/\#1a02deeb5ad5
} 
hesitant to intervene in Libya due to recent coalition campaigns in Iraq, Afghanistan, and Kosovo. ${ }^{154}$ While France was attempting to distance themselves from relationships with dictators, especially since they were one of Libya's largest arms suppliers, the United States was attempting to separate themselves from the notion that they are in the business of regime change. France was willing to separate ties while the United States was looking to preserve the current structure. However, structural ties with France trumped other U.S. interests.

The structural ties within the Libyan conflict network and their subsequent effect on the behavior of nodes appears to prove that actions taken in Libya may have not been the preferred policy. One of the main criticisms of U.S. involvement in the Libyan conflict was that they attempted to narrowly define their involvement, but their objectives continued to shift throughout the intervention. It appears that the reason for this shift was because the United States was intervening on behalf of their allies and not their own interests, aside from altruism, so their involvement shifted with the interest of their allies. However, it would appear that the concept of regime change was always a potential objective. The United States' past history of regime change coupled with their support for anti-Gaddi rebels who were attempting to topple his government, as well as Secretary Clinton's infamous "we came, we saw, he died" quote in reference to Gaddafi appear to show some level of support for regime change in Libya, even if the notion was repeatedly denied. ${ }^{155}$ Even though the United States had a responsibility to protect and an interest in stability in the region, it appears that their behavior and decision making was guided by other nodes within the conflict, primarily France and the United Kingdom. The criteria

\footnotetext{
${ }^{154}$ Con Coughlin, “Libya: Can Britain and France really run this conflict?” The Telegraph, March 22, 2011, https://www.telegraph.co.uk/comment/communists/concoughlin/8399184/Libya-Can-Britain-and-France-really-runthis-conflict.html

${ }^{155}$ Scott Shane \& Jo Becker, “A New Libya, With 'Very Little Time Left'," The New York Times, February 27, 2016, https://www.nytimes.com/2016/02/28/us/politics/libya-isis-hillary-clinton.html
} 
for intervention were altruism, the legality of intervention and international support, domestic constraints and public support, and the ability to shift responsibility to NATO. There had been very little public support for intervention, so it appears that it played a lesser role in decision making. Altruism was a necessary factor for the United States to even consider the possibility of intervention, but it appears that legal international support and the ability to shift responsibility onto NATO were the two most important factors. Due to the structure of NATO and their outspoken support for the intervention, the United States was able to play a lesser role than in previous interventions. However, it is not likely that the United States would have been as willing to intervene if it had not been for the pressure exerted from the Franco-British allies and their past relations.

\section{Syrian Conflict Case Study}

SNT Principle 1: Nodes are mutually dependent and influence each other's behavior.

The complexity of the Syrian conflict is attributed in part to the growing number of nodes within the Syrian conflict network. Similar to that of Libya, the Syrian conflict started out as domestic protests following the Arab Spring, which quickly turned into a civil war and then a regional conflict. The main nodes within the conflict are Syria, Russia, Turkey, Iran, the United States, ISIS, and anti-Assad rebels. There are numerous other nodes within the conflict, but they play a much more limited role. The United States' role in Syria has been heavily guided by the actions of the aforementioned nodes, and vice versa. When President Obama was first involved in the Syrian conflict it was due to humanitarian concerns. Syrian President Bashar Al-Assad has committed egregious human rights violations for over a decade and they have only continued to worsen under the guise of war. Early involvement and decision making were guided by the actions of Assad and Syria's patron state, Russia. As the war progressed, U.S. foreign policy in 
Syria became centered around the War on Terror and the actions of ISIS and other terrorist conglomerates in the region. However, their actions throughout the entirety of the conflict have been severely curbed by Russia, Turkey, and to some extent Iran. Humanitarian intervention has been avoided because Russia continuously votes down UNSC resolutions in favor of military force in Syria. Since the Security Council has been unable to pass a resolution, the United States has been unable to legally intervene. In addition, the lack of a legal basis for intervention and military involvement has deterred NATO from taking a hardline stance. NATO has been adamant about upholding the Geneva process, but has had limited success due to Russia and their role on the Security Council. In addition, Russia's involvement in the conflict has affected the United States' course of action. The United States has been careful about airstrikes and the ground fighting because of the location of Russian troops. American troops and anti-Assad rebels have come into direct contact with Russian mercenaries that are believed to have been acting on orders from the Kremlin, but the brief battle quickly dissipated out of fear into turning a bloody war. ${ }^{156}$ In addition, the United States has gone out of its way to warn Russian officials of airstrikes, essentially minimizing their effects.

U.S. involvement in Syria has been minimized further by the involvement of Turkey. Both Turkey and the United States are fighting against the Assad regime; however, they frequently butt heads because of American support for Kurdish rebels. Since Turkey has been a longstanding ally of the United States and helped the U.S. during the Iraq invasion, Washington has been hesitant to upset Ankara. U.S.-Turkish relations have been tenuous for over a decade and this has been reflective in U.S. foreign policy in Syria. Turkey has been instrumental in

\footnotetext{
156 Thomas Gibbons-Neff, "How a 4-Hour Battle Between Russian Mercenaries and U.S. Commandos Unfolded in Syria," The New York Times, May 24, 2018, https://www.nytimes.com/2018/0524/world/middleeast/americancommandos-russian-mercenaries-syria.html
} 
implementing America's train and equip program and has provided an insurmountable amount of assistance to Syrian refugees so that America does not have to shoulder the burden. However, the United States has forced Kurdish troops, and allegedly ISIS fighters, closer to the Turkish border, which has increased tensions. Turkey has repeatedly threatened U.S.-backed Kurdish forces, particularly amid a potential U.S. withdrawal from the region. ${ }^{157}$ Due to Turkish threats against Kurds, a U.S. withdrawal now hinders on the protection of Kurdish rebels. While there are other factors that contribute to the withdrawal, or if the withdrawal is actually reflective of U.S. foreign policy directives, the protection of Kurdish rebels has remained a top priority for the Trump Administration.

Another condition of U.S. withdrawal has to do with pushing Iranian boots out of Syria and diminishing their influence on the region; however, Washington's concern with Iran is twofold. Iran poses a threat to the United States' closest ally, Israel, as well as a regional threat in Syria. While the United States' actions in Syria have not been directly guided by Iran, they have been affected by them to some extent due to their ties with Israel. Israel and Iran have an ongoing proxy war within the Syrian conflict which further threatens stability in the region, as well as the safety as Israel since Syria and Israel share a border. Iranian forces have turned the tide in favor of Assad's government and the removal of American troops, one of Iran's only obstacles in the country, would "provide Iran with solid control over the entire arc of the levant from Baghdad to Beirut." ${ }^{58}$ Iran also poses a threat to the implementation of a political settlement in Syria in accordance with UNSCR 2254, which is included in the Trump

\footnotetext{
${ }^{157}$ Erin Cunningham, "Turkey threatens to 'bury' Kurdish forces in Syria amid U.S. withdrawal," The Washington Post, December 20, 2018, https://www.washingtonpost.com/world/turkey-threatens-to-bury-kurdish-militants-insyria-amid-us-withdrawal/2018/12/20/06d8eb18-0460-11e9-958c0a601226ff6b_story.html?utm_term $=.247 \mathrm{efb} 2 \mathrm{dc} 7 \mathrm{a} 1$

${ }^{158}$ Dan De Luce, Josh Lederman \& Courtney Kube, "Trump's withdrawal from Syria is victory for Iran and Russia, experts say," $N B C$, December 20, 2018, https://www.nbcnews.com/storyline/isis-uncovered/trump-s-withdrawalsyria-victory-iran-russia-experts-say-n950111
} 
Administration's three-party strategy. ${ }^{159}$ Iran is attempting to project power over Assad's government so that Iran may play a role in the reconstruction of Syria, essentially shaping the country's future and enlisting Syria as a client state. ${ }^{160}$ However, Iran has frequently been lumped in with terrorist conglomerates because of their continued support of Hezbollah, which may explain the more recent shift of concern towards Iranian influence. Iran frequently opts to use Shia militants instead of Iranian troops in order to minimize costs. As Iranian influence grows and their interests expand, Tehran may choose to redirect these forces to other conflicts, namely Afghanistan. ${ }^{161}$ Such a decision would further destabilize the region and compromise U.S. interests and campaigns in the Middle East, essentially leaving the door open for terrorist insurgents.

Numerous terrorist organizations were able to gain traction in Syria and Iraq during the onset of the Syrian conflict. The main terrorist organizations involved in the Syrian conflict are ISIS, Hezbollah, Jabhat Fateh al-Sham/al-Nusra Front, and the YPG even though the United States has been arming various Kurdish factions. The United States' War on Terror has been centered around fighting ISIS and to some extent al-Nusra Front, an offshoot of al-Qaeda. However, there has been much confusion with regards to who is fighting who and who is receiving arms. The United States was only legally allowed to put troops on the ground so that they may train rebel forces to fight against ISIS and in the War on Terror, but U.S. troops have frequently been involved in hostilities that did not include terrorists, such as the battle with Russian mercenaries. The United States did not attempt to intervene in Syria until 2014 when

\footnotetext{
159 "Remarks at the 36th Annual Jewish Institute for National Security of America Awards Dinner," U.S. Department of State, October 10, 2018, https://www.state.gov/secretary/remarks/2018/10/286559.htm ${ }^{160}$ Colin P. Clarke \& Ariane Tabatabai, “America's Indefinite Endgame in Syria," The Atlantic, October 16, 2018, https://www.theatlantic.com/international/archive/2018/10/bolton-pledges-american-troops-syria-iran/573121 161 Ibid.,
} 
they declared their War on Terror against ISIS and formed the U.S.-led coalition against them, just a few short months after the second Libyan civil war broke out. The United States was not legally allowed to attack Assad because they had not been attacked first and the UNSC was unable to pass a resolution, but the U.S. was able to legally become involved under U.S. law, namely the Authorization for Use of Military force Against Iraq Resolution of 2002 because ISIS formed out of al-Qaeda. Therefore, the actions of ISIS have had a direct effect on the level of involvement of U.S. troops in Syria.

SNT Principle 2: Ties between nodes serve as channels for the transmission of goods and information within networks.

Ties between the United States and other nodes within the Syrian conflict network have actually contributed to the complexity of the situation. For example, Turkey and Jordan were supposed to be intermediaries for the U.S. train and equip program of rebels; however, weapons and information was then supplied to people on the Jordanian black market. The aforementioned countries were supposed to distribute U.S. information and resources, essentially working as an extension of the CIA and American government. However, the CIA train and equip program, also known as Timber Sycamore, suffered a major setback when Jordanian intelligence began pilfering stockpiles of U.S. weapons intended for Syrian rebels and selling them on Jordan's black market where they were then presumably bought by insurgents. ${ }^{162}$ Timber Sycamore and U.S.-Jordanian relations suffered another blow when a Jordanian soldier killed three American troops that were working with the train and equip program in November $2016 .{ }^{163}$ These setbacks

\footnotetext{
${ }^{162}$ Mark Mazzetti, Adam Goldman, \& Michael S. Schmidt, "Behind the Sudden Death of a \$1 Billion Secret C.I.A. War in Syria," The New York Times, August 2, 2017, https://www.nytimes.com/2017/08/02/world/middleeast-ciasyria-rebel-arm-train-trump.html

${ }^{163}$ Rana F. Sweis, "Jordanian Sentenced to Life in Prison for Killing 3 U.S. Soldiers," The New York Times, July 17, 2017, https://www.nytimes.com/2017/07/17/world/middleeast/jordan-killing-us-soldiers.html?module=inline
} 
impacted other ties within the conflict and compromised the transmission of goods and information by diverting arms and intelligence intended for U.S. allies to terrorist organizations. The inadvertent arming of terrorist organizations and the inability to provide refugee camps with supplies and assistance has hurt existing ties within the conflict. Ties between nodes are supposed to serve as the transmission of goods and information, but some ties within the conflict have become knotted due to conflicting interests, namely ties between the U.S. and Turkey and the U.S. and Kurdish rebels. There has also been somewhat of a failure to transmit information since the United States and Russia are both permanent members of the UNSC and they have vastly different vested interests in the conflict. The knotting of ties may be found in all three principles of SNT, most notably the structure of the network, how the knots influence behavior, and how it impacts the transmission of information. With regards to Turkey, the knot resulted in the U.S. prioritizing relations with Kurdish rebels over their ties with Turkey. Similarly, Russia's ties with Syria came before their ties with the U.S., which hindered their ability to fully transmit goods and information as it pertains to military involvement and humanitarian efforts. However, since Russia and the U.S. are both members of the council, communication and the transmission of some information between the two countries has been more apparent. Yet it has created an inability for the UN and the international community to take further action with regards to the Syrian conflict and the ongoing human rights violations that stem from its violence. R2P still stands, but it has little footing since the UNSC cannot pass a resolution because of the likes of Russia and China.

The United States has kept up other forms of communication with Russia with regards to the Syrian conflict due to ties between Trump and Putin. There have been more conversations and meetings between the two countries than there were under the Obama Administration; 
however, there may have also been more concessions. Putin and Trump have implemented deescalation zones in Syria that have allowed Assad's regime to gain more ground, which is great for the United States and Russia because it prevents them from plunging into war against each other, but it has done little to protect Syrian civilians, especially since the United States refuses to provide aid to areas that are being held by Assad. ${ }^{164}$ By making concessions to Russia, the United States is essentially making concessions to Syria and Iran as well. The United States entered Syria under the guise of the War on Terror and feigned humanitarian concerns, but instead of putting those concerns first, the United States has made concessions to its adversaries and claimed to have defeated ISIS, even though this has been proven false. To take it a step further, the United States has actually aided the exact terrorist organizations it claims to be fighting through its ties that it went out of its way to create. While arming rebels may have been well intentioned, it resulted in supplying ISIS and al-Nusra Front with arms and ammunition. ${ }^{165}$ Their relationship with Kurdish rebels and the alleged orders to rebels to move ISIS fighters to Assad-held regions in Eastern Syria also calls into question what American policy in Syria truly is. Is the United States fighting a War on Terror? Is the United States supporting rebels to put an end to Assad's human rights change? Or, is this limited involvement another ploy by the United States to implement regime change? The United States has been rather inconsistent with which relationships it prioritizes most within the conflict, therefore which nodes the U.S. chooses to share goods and information. The answers to the aforementioned questions would ultimately shed light on U.S. foreign policy in Syria, as well as provide an explanation to Washington's

\footnotetext{
${ }^{164}$ Anna Borshchevskaya, "How Putin Checkmated the US in Syria," Forbes, September 26, 2017, https://www.forbes.com/sites/annaborshchevskaya/2017/09/26/how-putin-checkmated-the-us-insyria/\#1 fbb0ee767e8

${ }^{165}$ Hollie McKay, "'I gave the US trucks and ammunition to Al Qaeda': The chaotic US effort to arm Syrian rebels," Fox, May 15, 2018, https://www.foxnews.com/world/i-gave-the-us-trucks-and-ammunition-to-al-qaeda-thechaotic-us-effort-to-arm-syrian-rebels
} 
shifting international relations within the conflict and why they have at times worked with adversaries over allies in order to achieve their goals. In turn, these answers may help explain when the United States will prioritize humanitarian concerns over other interests.

SNT Principle 3: Ties within a given network have the ability to create structures which may influence nodes' behavior.

Ties within the Syrian conflict have greatly affected the structures of the conflict as well as the behavior of involved nodes. For the United States, the well-being of their allies appears to come first. For example, the United States will not withdrawal troops without first expelling Iranian boots and influence from Syria. By doing this, the United States is curbing Iranian influence in the region and their potential to harm Israel, as well as Iran's ability to employ Hezbollah to do its dirty work in both Syria and Israeli-Palestinian territories. While the IsraeliIranian proxy war has not played a major role in U.S. decision-making in Syria, it has added a level of U.S. involvement and a criterion for withdrawal. In addition, protection of U.S.-backed Kurds has played a similar role. The United States and Turkey have been allies for decades, but the United States still chose to risk severing ties with Turkey in order to support the rebels. U.S.Turkish relations have been able to withstand the Syrian conflict, but they have been severely weakened due to growing mistrust and a growing difference in opinion. Future action against U.S.-backed Kurds by Turkish forces may be what severs the tie between Washington and Ankara. It still remains somewhat unclear why the United States chose to favor Kurdish rebels over Turkey, but it may have to do with Turkey's actions throughout the conflict. Turkey has been a bad ally at times, arming al-Nusra Front and providing military equipment to ISIS. ${ }^{166}$ The United States' inability to trust Turkey led them to the arms of the Kurds, a "a reliable and

\footnotetext{
${ }^{166}$ Sherko Kirmanj, "8 Reasons Why America Supports the Syrian Kurds," National Interest, September 13, 2017, https://nationalinterest.org/feature/8-reasons-why-america-supports-the-syrian-kurds-22290
} 
capable force" of fighters that were best equipped to prevent cross border movement of terrorists due to their history of dealing with such organizations and their strategic location. ${ }^{167}$

With regards to Russian-American ties, the relationship is even more complex. Despite the Trump Administration's efforts to make Russia America's ally, they are still adversaries. Trump and Putin's rhetoric towards one another paints a rosier picture than either countries' foreign policy truly reflects. The February 2018 battle between American troops and Russian mercenaries was the closest Russian and American forces have been to colliding with one another since before the Cold War. ${ }^{168}$ The fear of plunging both countries into a bloody battle has been a guiding factor in decision-making. In order to prevent further clashes, either country has warned of future attacks as a means of deterrence and has helped create de-escalation zones as a weak attempt at feigning cooperation. War between the U.S. and Russia is more than what either country wants, or can handle, which is why preserving what is left of their icy ties has remained a top priority. However, these structural ties are far-reaching, which is why the United States has been reluctant to take further action against Assad. Since Syria and Russia are so close, an attack on Assad would be seen as an attack on the Kremlin. Even though the U.S. started treating the Syrian conflict as a War on Terror under the Obama Administration, it has since been used by the Trump Administration as a way to distance themselves from the initial reason the United States took an interest in Syria: egregious human rights violations perpetrated by the Assad regime. Trump's repeated claims that his only reason for being in Syria is because of ISIS is deeply misguided. Assad continues to kill his own people and has even killed an

\footnotetext{
167 Ibid,

168 Thomas Gibbons-Neff, "How a 4-Hour Battle Between Russian Mercenaries and U.S. Commandos Unfolded in Syria," The New York Times, May 24, 2018, https://www.nytimes.com/2018/0524/world/middleeast/americancommandos-russian-mercenaries-syria.html
} 
American civilian on a humanitarian mission, yet the United States has turned a blind eye to such atrocities.

While there is a structural hierarchy within the Syrian conflict network, it appears that Russia remains a top tie to maintain. This does not mean that lesser ties are irrelevant, rather they are used to manipulate ties between the United States and Russia. For example, the relocation of ISIS fighters within pro-government held regions may have been a way for the United States to strike against Assad and Russia inadvertently. By hiding behind terrorists they are supposed to be fighting, the United States was able to hurt Russian and Syrian forces. The plan may have even been a twofold attempt at harming Turkey as well by bringing Kurdish rebels and ISIS fighters to their doorstep as Turkey claims to have been left in the dark on this decision, presumably because they would have fought against such a move. ${ }^{169}$ The move would have taken place around October 2017 when the Battle of Raqqa ended, a time at which U.S.-Turkish relations were deteriorating and both countries stopped issuing visas to each other's citizens, which bolsters the idea of a twofold motive. ${ }^{170}$ The War on Terror and the ties between the United States and various terrorist organizations has been used a tool in the Syrian conflict. While terrorists do pose a significant threat in the region, the War on Terror has distracted the international community from the failures of the Libyan intervention and its subsequent civil war, the inability of the United States to legally act in Syria against Assad, and the reluctance of the international community to intervene. Even though the United States and ISIS are enemies, it has not stopped the United States government from using ISIS fighters as pawns to achieve their

\footnotetext{
169 Dominic Evans \& Orhan Coskun, "Defector says thousands of Islamic State Fighters left Raqqa in secret deal," Reuters, December 7, 2017, https:/www.reuters.com/article/us-mideast-crisis-syria-defector/defector-saysthousands-of-islamic-state-fighters-left-raqqa-in-secret-deal-idUSKBN1E12AP

${ }^{170}$ Carlotta Gall, "U.S. and Turkey Try to Prevent a Diplomatic Dispute from Growing," The New York Times, October 9, 2017, https://www.nytimes.com/2017/10/09/world/europe/us-turkey-visas.html
} 
goals. The willingness to use terrorists as tools instead of defeating them when they are offered the chance may put a cloud of doubt over the War on Terror and the ulterior motives of the U.S. Criteria for Humanitarian Intervention in Syria

In comparison to Libya, the criteria for humanitarian intervention in Syria is lacking. Intervention in Libya was possible due to the forcefulness of the Franco-British coalition. They were adamant about employing the United States in their efforts and were successful in passing two UNSC resolutions that gave a legal basis for military intervention. While both France and the United Kingdom are involved in the Syrian conflict, they have been more hesitant to act in comparison to their previous military endeavor. Even when France was ready to act and called for intervention after Assad's use of chemical weapons on civilians and Obama's redline speech, the United States refused to act, essentially nullifying Obama's threat and sending a message to Assad that there would not be consequences for his actions. Since the UK and France are involved in the Syrian conflict, as well as a number of other NATO member states, there is some level of military support for military action. However, NATO's involvement has been limited to enforcing the Geneva process. In Libya, NATO enforced the no-fly zone and implemented the intervention. In Syria, NATO is unable to offer the same level of support, which means the United States is not able to shift responsibility onto NATO or their allies. However, there has been significantly more support for military involvement in Syria than there was in Libya. While the numbers are not as high as they were for past interventions, namely Iraq and Afghanistan, they still remain higher than public support for intervention in Libya. However, levels of altruism appear to have been higher in the Libyan intervention than in the Syrian conflict. While humanitarian concerns were present in both conflicts, they appear to be more limited in Syria. The decision to bar Syrian refugees from entering the United States, the refusal to aid Syrians in 
areas under government control, and the insistence that U.S. involvement in Syria is strictly attributed to War on Terror seems to insinuate that altruism and humanitarian concerns have taken a back seat to other U.S. interests.

The reliance on allies and NATO for involvement in conflicts and the criteria for humanitarian intervention points back to the principles of SNT. Nodes within a conflict network are dependent upon one another and influence each other's behavior. These nodes then transmit goods and information via their ties within a network. The ties between nodes may create a structural hierarchy, which will then affect all other relations within the network. It would appear that both the Libyan and Syrian conflicts were and are heavily guided by the nodes within each network. The existing nodes and their subsequent ties determine how goods and information are transmitted between actors, which ultimately shapes the outcome of such a conflict. Furthermore, the structural hierarchy of nodes within a given conflict is of the utmost importance as the hierarchy shapes and severs ties within the network. The United States is lacking strong ties within the conflict network and a legal basis for intervention, which puts them in a precarious situation. Intervention was plausible in Libya because of the pressure from other nodes and the international community, as well as the involvement of NATO, which is not present to the same degree in Syria. In addition, Libya did not have international support whereas Syria and Assad's regime have the backing of Russia and Iran, which again hinders U.S. involvement. Tenets of the responsibility doctrine were present in the Libyan conflict, but appear to be lacking with regards to Syria. Other countries were willing to step up and take a more hands-on approach in Libya, presumably because they were quickly isolated by the international community, but the Syrian conflict has not unfolded in the same manner. Countries like Turkey and Jordan played a larger 
role in Syria because of their regional proximity, but they were often acting on behalf or in conjuncture with the United States because of their existing ties. 


\section{CHAPTER VII: CONCLUSION}

Due to the unpredictable nature of the current Administration, it may be difficult to come to a concrete conclusion as to what course of action the United States may take in the future. However, due to the similar natures of the Libyan and Syrian conflicts and an overlapping of key actors, it is possible to determine a potential outcome. Intervention in Libya has served as a strong basis for the criteria necessary in Syria. In conjuncture with social network theory, these criteria and the relations the U.S. has with involved actors provides insight into the United States' decision-making process and when the use of violence in the name of humanitarian intervention may be seen as a top priority. However, the question of why the United States has not resorted to alternative means of force in Syria and when humanitarian concerns will become a top priority still remains somewhat unclear. While it is difficult to provide a definitive answer as to when the United States will prioritize humanitarian concerns over other interests, it may be argued that they will only do so when such prioritization of human rights will benefit either the United States or its allies.

Humanitarian concerns in Libya played an important role in the decision to intervene because a lack of action would have posed a threat to new security challenges, such as energy security and migration. However, altruism was not enough for intervention, it was not until the interests of the United States and their allies were threatened by Gaddafi's human rights abuses that the United States decided to act. The United States has been able to avoid these concerns in Syria due to a lack of economic relations with Syria because of decades of economic sanctions coupled with the decision to stop admitting refugees from Syria and Iraq. The United States has little to lose in Syria, but has everything to gain if they can spread their influence across the country and are able to steal Russia's foothold in the Middle East. The United States has become 
notorious for military interventions and regime changes across the Middle East and North Africa, and has tarnished their reputation in doing so. However, they are attempting to save face through their role in Syria. Even though the United States initially supported anti-Assad supporters that were fighting for regime change, they have since shifted their narrative towards Kurdish rebels that are fighting in the War on Terror. While the United States is still involved in the Syrian conflict, they are playing a more indirect role than in previous interventions. However, they will have limited success if they do not address the ongoing nature of the Syrian conflict.

By shifting efforts towards the War on Terror and the reluctance to take further action because of Russia, the United States has contributed to the prolongation of the Syrian conflict and the refugee crisis that stems from the ongoing violence. ISIS and other terrorist organizations are able to thrive in Syria only because of the desperation and disarray that has been sewn by the war. If the United States were to shift efforts towards fighting Assad's brutal regime and seeking justice for the human rights violation he and his government have perpetrated, they would be able to crack down on the War on Terror. Similarly, the same could have been said about the Libyan intervention. While the United States and its allies fought against Gaddafi, they failed to address the vulnerable state it left the country in, which left it susceptible to infiltration by terrorist cells. The implementation of peacebuilding efforts targeted at the root causes of both conflicts would have been beneficial in preventing further instability and disarray. However, it is not likely that the United States will shift military operations in campaign towards Assad.

It is difficult to conclude what the United States' preferred policy is, or if there even is one considering the amount of times objectives have shifted over the course of the Syrian conflict. However, shifting objectives may be attributed to other factors. Since the United States is constrained by the actions of Russia and is hoping to avoid another war, they have been 
reluctant to take direct action against Assad. Even though the United States has conducted airstrikes and put boots on the ground, they have been done at much lower rates in comparison to that of Libya. In Libya, the only adversary of the United States in the conflict was Libya, and that was only partially true since their relations had been on the mend for the last few years. In the Syrian conflict, it seems like a new adversary appears every day. This has left the United States unable to act against Assad without running the risk of upsetting Russia and Iran and laying the groundwork for further terrorist insurgencies because of growing instability. Almost a decade of fighting has ravaged the country and erased any answer as to what the right course of action might be. Even if the criteria for humanitarian intervention are present in Syria in comparison to Libya, it is not likely that intervention at a comparable scale will be pursued. The conflict has become too complex with too many involved nodes with differing agendas for an intervention and peacebuilding efforts to be implemented successfully. In order for the United States to truly prioritize humanitarian concerns, they need to focus on assistance to refugees and internally displaced Syrians. Further military involvement will only create more refugees and result in more casualties, as well as threaten U.S. relations with Russia.

Complex conflicts may be better understood if they are looked at through the lens of social network theory. While some of the principles of the theory may seem overtly obvious, they are often overlooked despite being beneficial to peacebuilding and avoiding violence altogether. By understanding the social networks of conflicts and their internal hierarchies regarding nodes, researchers and politicians alike will have a greater understanding of the guiding forces and interests of the conflict. Even if a concreate conclusion may not be drawn, it will create clarity out of the unclear. One of the main issues with intervention and peacebuilding is that the root causes of the conflict are not fully understood, but they are believed to be. If 
politicians and research are made aware of the things they do not fully know, it allows them to pursue answers instead of assumptions. While concreate conclusions often cannot be made without hindsight, inferences may be made from applying social network theory to violent conflicts in the future. By knowing who shares a network, who runs the network and influences the behavior of other actors the most, and how actors transmit goods and information, it will shed insight on the conflict that was not previously known, or was inaccurately perceived to have been understood.

Inferences from the Libyan conflict and Syrian case study may be made with regards to current policy in Syria as well as potential conflicts in the future. While there appears to be some degree of altruism, particularly from the American people as public support for military intervention is higher in comparison to Libya, it is not enough. The United States does have allies fighting in the conflict, but they all have too little to gain from a large-scale military intervention, unlike in Libya. In addition, since they do not have a legal basis for intervention, it is unlikely that the United States will take a more extreme form of action as it pertains to humanitarian concerns. Not only would such a decision put direct responsibility on the United States since NATO is not heavily involved, it would also leave them susceptible to international retaliation because military intervention without a legal basis violates international law. While there has been an outcry for humanitarian assistance from the American public sporadically over the course of the war, the U.S. government has often acted in direct opposition to such concerns, namely by banning Syrian refugees from entering the country and by blocking aid to Syrian civilians in government held regions. Unfortunately for Syrians, it appears they are stuck in a perfect storm and will have to continue to ride out the tidal waves of violence for an unknown amount of time towards an uncertain future. It is not likely that the United States will take further 
action in Syria, or prioritize human rights over other concerns, until the structural hierarchy of the conflict changes or until Assad's human rights violations begin to 'interfere with other U.S. interests. With that, inferences may be made arguing that since the invasion of Iraq, U.S. interventions have adhered to realism and self-serving interests in comparison to past interventions born of liberalism and humanitarian concern. 


\section{REFERENCES}

Al Jazeera. “Arab states seek Libya no-fly zone.” March 12, 2011. https://www.aljezeera.com/news/africa/2011/03/201131218852687848.html

Baker, Peter \& Michael R. Gordon. "Kerry Becomes Chief Advocate for U.S. Attack." The New York Times. August 30, 2013. https://www.nytimes.com/2013/08/31/world/middleeast/ john-kerry-syria.html

Baruch, Pnina Sharvit \& Brandon Weinstock. "Military Intervention in Syria: Is It Legal?” The Institute for National Security Studies. September 11, 2013. http://www.inss.org.il/ publication/military-intervention-syria-legal/

Baxter, Pamela \& Susan Jack. “Qualitative Case Study Methodology: Study Resign and Implementation for Novice Researchers.” The Qualitative Report. vol. 13(4), December 1, 2008. https://nsuworks.nova.edu/cgi/viewcontent.cgi?article=1573\&context=tqr

Becker, Jo \& Scott Shane. “The Libya Gamble: Hillary Clinton, 'Smart Power' and a Dictator's Fall.” The New York Times. February 27, 2016. https://www.nytimes.com/2016/02/28/us/ politics/ hillary-clinton-libya.html?_r=0

British Broadcasting Corporation. "IS 'caliphate' defeated but jihadist group remains a threat." March 23, 2019. https://www.bbc.com/news/world-middle-east-45547595

British Broadcasting Corporation. "US to expel every las Iranian boot from Syria - Pomepo." January 10, 2019, https://www.bbc.com/news/world-middle-east-46828810

Blomdahl, Mikael. "Interacting Interests: Explaining President Obama's Libyan Decision.” European Journal of American Studies. vol. 13(2). 2018. https://journals.openedition.org/ejas/13224 
Borshchevskaya, Anna. "How Putin Checkmated the US in Syria." Forbes. September 26, 2017. https://www.forbes.com/sites/annaborshchevskaya/2017/09/26/how-putin-checkmatedthe-us-in-syria/\#1 fbb0ee767e8

Castells, Manuel. Communication Power. Oxford: Oxford University Press. 2009.

Chulov, Martin. "Arab League to reiterate backing for Libya no-fly zone.” The Guardian. March 22, 2011. https://www.theguardian.com/world/2011/mar/22/arab-league-libya-no-fly

Clarke, Colin P. \& Ariane Tabatabai. “America's Indefinite Endgame in Syria.” The Atlantic. October 16, 2018. https://www.theatlantic.com/international/archive/2018/10/boltonpledges-american-troops-syria-iran/573121

Cohen, Zachary. "Lindsey Graham says Trump's Syria statements emboldened ISIS.” CNN. January 16, 2019. https://www.cnn.com/2019/01/16/politics/graham-syria-attacktrump/index.html

Coker, Christopher. The Future of War: The Re-Enchantment of War in the Twenty-First Century. Malden: Blackwell Publishing Ltd. 2004.

Conflict Armament Research. "Weapons of the Islamic State: A three year investigation in Iraq and Syria.” December 2017.

Congress.Gov. "H.J. Res. 124-Continuing Appropriations Resolution, 2015.” September 19, 2014. https://www.congress.gov/bill/113th-congress/house-joint-resolution/124/ text?overview $=$ closed

Coughlin, Con. "Libya: Can Britain and France really run this conflict?" The Telegraph. March 22, 2011. https://www.telegraph.co.uk/comment/communists/concoughlin/8399184/ Libya-Can-Britain-and-France-really-run-this-conflict.html 
Cunningham, Erin. “Turkey threatens to 'bury' Kurdish forces in Syria amid U.S. withdrawal." The Washington Post. December 20, 2018. https://www.washingtonpost.com/world/ turkey-threatens-to-bury-kurdish-militants-in-syria-amid-us-withdrawal/2018/12/20/ 06d8eb18-0460-11e9-958c-0a601226ff6b_story.html?utm_term=.247efb2dc7a 1

Davey, Lynn. "The Application of Case Study Evaluations." Practical Assessment, Research \& Evaluation, vol. 2(9). 1991. https://pareonline.net/getvn.asp?v=2\&n=9

De Luce, Dan, Josh Lederman \& Courtney Kube. “Trump's withdrawal from Syria is victory for Iran and Russia, experts say.” $N B C$, December 20, 2018. https://www.nbcnews.com/story line /isis-uncovered/trump-s-withdrawal-syria-victory-iran-russia-experts-say-n950111

Doherty, Carroll. "Possible chemical weapons use by Syria has influenced public support for action in past polls." Pew Research Center. August 22, 2013. http://www.pewresearch.org /fact-tank/2013/08/22/possible-chemical-weapons-use-by-syria-has-influenced-publicsupport-for-action-in-past-polls/

Dorussen, Han, Erik Gartzke, \& Oliver Westerwinter. "Networked international politics: Complex interdependence and the diffusion of conflict and peace." Journal of Peace Research. vol. 55(3). 2016.

Drought, Rebecca. “UK Border controls - are they tough enough?” British Broadcasting Corporation. November 9, 2011. https://www.bbc.com/new/uk-15638607

Doucet, Lyse. "Syria \& the CNN Effect: What Role Does the Media Play in Policy-Making?" Daedalus: Journal of the American Academy of Arts \& Sciences. vol. 147(1). Winter 2018. https://www.mitpressjournals.org/doi/full/10.1162/DAED_a_00480

Elliott, Michael. "Viewpoint: How Libya Because a French and British War." Time, March 19, 2011. content.time.com/time/world/article/0,8599,2060412,00.html 
Erlanger, Steven. "France and Britain Lead Military Push on Libya." The New York Times. March 18, 2011. https://www.nytimes.com/2011/03/19/world/africa/19europe.html Fisher, Max. "The one map that shows why Syria is so complicated." The Washington Post. August 27, 2013. https://www.washingtonpost.com/news/worldviews/wp/2013/ 08/27/the-one-map-that-shows-why-syria-is-so-complicated/?utm_term=.39c4eaa92bc5

Evans, Dominic \& Orhan Coskun. "Defector says thousands of Islamic State Fighters left Raqqa in secret deal.” Reuters. December 7, 2017. https://www.reuters.com/article/us-mideastcrisis-syria-defector/defector-says-thousands-of-islamic-state-fighters-left-raqqa-insecret-deal-idUSKBN1E12AP

Forbes. "France, U.K. Have differing Motives for Intervening in Libya.” March 29, 2011. https://www.forbes.com/sites/energysource/2011/03/29/france-u-k-have-differingmotives-for-intervening-in-libya/\#1a02deeb5ad5

Friedman, Thomas. "Obama on the World." The New York Times. August 8, 2014. https://www.nytimes.com/2014/08/09/opinion//president-obama-thomas-1-friedman-iraqand-world-affairs.html?_r=0

Gall, Carlotta. "U.S. and Turkey Try to Prevent a Diplomatic Dispute from Growing." The New York Times. October 9, 2017. https://www.nytimes.com/2017/10/09/world/europe/usturkey-visas.html

Gerring, John. "What Is a Case Study and What Is It Good for?" The American Political Science Review, vol. 98(2). 2004. https://www-jstor-org.libproxy.lib.ilstu.edu/stable/pdf/4145316. pdf?refreqid=excelsior\%3Ae05e05c3b36ac4f764fdd458cd2796eb 
Gibbons-Neff, Thomas. "How a 4-Hour Battle Between Russian Mercenaries and U.S.

Commandos Unfolded in Syria.” The New York Times. May 24, 2018.

https://www.nytimes.com/2018/0524/world/middleeast/american-commandos-russianmercenaries-syria.html

The Guardian. "Barack Obama statement on US intervention in Syria - full text." August 31, 2013. https://www.theguardian.com/world/2013/aug/31/barack-obama-statement-usintervention-syria

The Guardian. "EU arms exports to Libya: who armed Gaddafi?” March 2, 2011.

https://www.theguardian.com/news/datablog/2011/mar/01/eu-arms-exports-to-libya

The Guardian. "EU lifts Libya Sanctions.” October 11, 2004. https:/www.theguardian.com/ world/2004/oct/11/libya.eu

The Guardian. "Immigration to the UK: the key facts.” https://www.theguardian.com/news/ datablog/2010/jun/26/non-eu-immigration-uk-statistics

Habets, Ingrid. “Obstacles to a Syrian peace: the interference of interests." European View. vol. 155. 2016. https://journals.sagepub.com/doi/pdf/10.1007/s12290-016-0397-3

Hamid, Shadi. "Everyone says the Libya intervention was a failure. They're wrong." Brookings Institution. April 12, 2016. https://www.brookings.edu/blog/markaz/2016/04/12everyonesays-the-libyan-intervention-was-a-failure-theyre-wrong/

Hamidi, Ibrahim. "Syrian Opposition Fighters Withdraw from US 'Train and Equip' Program.” The Syrian Observer. June 22, 2015. https://syrianobserver.com/EN/news/29743/ syrian_opposition_fighters_withdraw_from_us_train_equip_program.html 
Hartig, Hannah. "Republicans turn more negative toward refugees as number admitted to U.S. plummets." Pew Research Center. May 24, 2018. http://www.pewresearch.org/facttank/2018/05/24/republicans-turn-more-negative-toward-refugees-as-number-admittedto-u-s-plummets/

Hayes, Richard, Brittany Kyer, \& Emily Weber. “The Case Study Cookbook.” December 2105. https://web.wpi.edu/Pubs/E-project/Available/E-project-121615164731/unrestricted/USPTO_CookbookFinal.pdf

Home Office. "Control of Immigration: Quarterly Statistical Summary, United Kingdom.” https://assets.publishing.service.gov.uk/government/uploads/system/uplods/attachment_d ate/file/116083/control-immigration-q1-2011.pdf

Horsley, Scott. “U.S. Intervention in Libya: A Noble Use of Force?” NPR. March 28, 2011. https://www.npr.org/2011/03/28/134927059/u-s-intervention-in-libya-a-noble-use-offorce

Human Rights Watch. “A Wasted Decade: Human Rights in Syria during Bashar al-Asad's First Ten Years.” July 16, 2010. https://www.hrw.org/report/2010/07/16/wasteddecade/human-rights-syria-during-bashar-al-asads-first-ten-years-power\#

Human Rights Watch. “Syria: Stories Behind Photos of Killed Detainees.” December 16, 2015. https://www.hrw.org/news/2015/12/16/syria-stories-behind-photos-killed-detainees Humund, Carla E., Christopher M. Blanchard, \& Mary Beth D. Nikitin. “Armed Conflict in Syria: Overview and U.S. Response.” Congressional Research Service. January 2, 2019. https://fas.org/sgp/crs/mideast/RL33487.pdf

Jenkins, Brian Michael. “The Dynamics of Syria’s Civil War.” RAND Corporation. 2014. https://www.rand.org/content/dam/rand/pubs/perspectives/PE100/PE115/RAND_PE115.pdf 
Jones, Jeffrey M. “Americans Again Opposed to Taking In Refugees.” Gallup. November 23, 2015. https://news.gallup.com/poll/186866/americans-again-opposed-takingrefugees.aspx

Jones, Jeffrey M. “Americans Approve of Military Action Against Libya, 47 to 37\%." Gallup. March 22, 2011. https://news.gallup.com/poll/146738/americans-approve-militaryaction-against-libya.aspx

Kadushin, Charles. Understanding Social Networks: Theories, Concepts, and Findings. Oxford: Oxford University Press. 2012.

Kern, Soeren. "Why France Was So Keen to Attack Libya." Gatestone Institute International Policy Council. March 23, 2011. https://www.gatestoneinstitute.org/1983/france-libyaattack

Kirmanj, Sherko. "8 Reasons Why America Supports the Syrian Kurds." National Interest. September 13, 2017. https://nationalinterest.org/feature/8-reasons-why-america-supportsthe-syrian-kurds-22290

Kramer, Christian. Network Theory and Violent Conflicts: Studies in Afghanistan and Lebanon. Cham: Springer Nature. 2017.

Kupchan, Charles A. \& Bernard Gwertzman. "Libya's Strains on NATO.” Council on Foreign Relations. April 4, 2011. https://www.cfr.org/interview/libyas-strains-nato

Landis, Joshua. “The U.S.-Syria Relationship: A Few Questions.” Middle East Policy Council. vol. 17(3). Fall 2010. https://www.mepc.org/us-syria-relationship-few-questions Landler, Mark. "U.S. Considers Resuming Nonlethal Aid to Syrian Opposition.” The New York Times. January 9, 2014. https://www.nytimes.com/2014/01/10/world/middleeast/syriaaid-may-resume-despite-fears-over-where-it-will-go.html 
Levesque-Alam, M. Junaid. “Arab League Walks a Tightrope With Libya Intervention.” Foreign Policy in Focus. March 22, 2011.

https:/fpif.org/arab_league_walks_a_tightrope_with_libya_intervention/

Libya Oil Almanac: An OpenOil Reference Guide. openoil.net/wp/wp-content/uploads/ 2012/08/Libya-PDF-v-2.0.pdf

Lipton, Eric. "Libya Seeks Exemption for Its Debt to Victims." The New York Times. April 22, 2008. https://www.nytimes.com/2008/04/22/washington/22libya.html

Little, Allan. "Libya: US, UK and France attack Gaddafi forces.” British Broadcasting Company. March 20, 2011. https://www.bbc.com/mews/world-africa-12796972

Little, Richard. "Revisiting intervention: a survey of recent developments." Review of International Studies. vol. 13(1). January 1987. https://www.jstor.org/stable/20097100? seq=1\#metadata_info_tab_contents

Mann, Bruce. Selected Styles in Web-Based Educational Research. Hershey: Information Science Publishing. 2006.

Mann, James. The Obamians: The Struggle Within the White House to Redefine American Power. New York: Penguin Group. 2012.

Martinez, Jose Ciro \& Brent Eng. "Struggling to Perform the State: The Politics of Bread in the Syrian Civil War.” International Political Sociology. vol. 11. 2017. https://academic.oup.com/ips/articleabstract/11/2/130/2875287

Mazzetti, Mark, Adam Goldman, \& Michael S. Schmidt. "Behind the Sudden Death of a \$1 Billion Secret C.I.A. War in Syria.” The New York Times. August 2, 2017. https://www. nytimes.com/2017/08/02/world/middleeast-cia-syria-rebel-arm-train-trump.html 
Mazzetti, Mark \& Ali Younes. “C.I.A. Arms for Syrian Rebels Supplied Black Market, Official Says.” The New York Times. June 26, 2016. https://www.nytimes.com/2016/06/27/world/ middleeast/cia-arms-for-syrian-rebels-supplied-black-market-officials-say.html

McKay, Hollie. "'I gave the US trucks and ammunition to Al Qaeda': The chaotic US effort to arm Syrian rebels.” Fox. May 15, 2018. https://www.foxnews.com/world/i-gave-the-ustrucks-and-ammunition-to-al-qaeda-the-chaotic-us-effort-to-arm-syrian-rebels

Meikle, James \& Ian Black. "Muammar Gaddafi says he will die a martyr rather than quit." The Guardian. February 22, 2011. https://www.theguardian.com/world/2011/feb/22/ muammar-gaddafi-libyan-tv-martyr

Miklaszewski, Jim \& Courtney Kube. "U.S. Admits Syrian Rebels Gave Trucks, Ammo to Al Qaeda-Linked Group.” NBC News. September 22, 2015. https://www.nbcnews.com/news /world/u-s-admits-syrian-rebels-gave-weapons-al-qaeda-linked-n434096

Newman, Edward, \& Oliver Richmond. "Peace building and spoilers." Conflict, Security \& Development, vol. 6(1). 2006. DOI: 10.1080/14678800600590728

North Atlantic Treaty Organization. "Statement by the North Atlantic Council on Actions taken against the use of chemical weapons in Syria.” April 14, 2018. https://www.nato.int/cps/en/natohq/news153670.htm

Obama, Barack. "President Obama Speaks on the Turmoil in Libya: "This Violence Must Stop."” The White House, Office of the Press Secretary. February 23, 2011.

Obama, Barack. "Remarks by the President in Address to the Nation on Libya." March 28, 2011. https://obamawhitehouse.archives.gov/the-press-office/2011/03/28/remarks-presidentaddress-nation-libya 
Obama, Barack. "Speech Given at the National Defense University.” March 28, 2011. http://www.whitehouse.gov/the-press-office/2011/03/28/remarks-president-addressnation-libya

Oweis, Khaled Yacoub. "Syria's Assad vows to life emergency law by next week." Reuters. April 16, 2011. https://www.reuters.com/article/us-syria/syrias-assad-vows-to-liftemergency-law-by-next-week-idUSTRE72N2MC20110416

Parlapiano, Alicia, Anjali Singhvi, Jon Huang, \& Thomas Kaplan. "Where Top Lawmakers Stand on Syria: Now and in 2013.” The New York Times, April 7, 2017. https://www.nytimes.com/interactive/2017/04/07/us/politics/congress-quotes-on-syriaairstrikes.html

Pew Research Center. "Public Wary of Military Intervention in Libya: Broad Concern that US Military is Overcommitted." March 14, 2011. http://www.peoplepress.org/2011/03/14/public-wary-of-military-intervention-in-libya/

Reinhart, RJ. "Snapshot: Half of Americans Approve of Strikes on Syria.” Gallup. April 24, 2018. https://news.gallup.com/poll/232997/snapshot-half-americans-approve-strikessyria.aspx

Rupar, Aaron. "Trump can't decide if the US has defeated ISIS.” Vox. January 7, 2019. https://www.vox.com/policy-and-politics/2019/1/7/18172063/trump-isis-commentincoherent

Santini, Ruth Hanau \& Arturo Varvelli. "The Libyan Crisis Seen from European Capitals." Brookings. June 1, 2011. https://www.brookings.edu/research/the-libyan-crisis-seenfrom-european-capitals/ 
Schmitt, Eric, Ben Hubbard, \& Rukmini Callimachi. "ISIS Attack in Syria Kills 4 Americans, Raising New Worries About Troop Withdrawal.” The New York Times. January 16, 2019. https://www.nytimes.com/2019/01/16/world/middleeast/isis-attack-syria-troops.html

Scotto, Angelo. "From Emigration to Asylum Destination, Italy Navigates Shifting Migration Tides." Migration Policy Institute. August, 24, 2017. https://www.migrationpolicy.org/ article/emigratio-asylum-destination-italy-navigates-shifting-migration-tides

Security Council Report. “S/RES/1970.” February 26, 2011.

https://www.securitycouncilreport.org/un-documents/document/libya-s-res-1970.php

Security Council Report. “S/RES/1973.” March 17, 2011.

https://www.securitycouncilreport.org/un-documents/document/Libya-S-RES-1973.php

Shane, Scott \& Jo Becker. “A New Libya, With 'Very Little Time Left'.” The New York Times. February 27, 2016. https://www.nytimes.com/2016/02/28/us/politics/libya-isis-hillaryclinton.html

Shelton, Tracey. "Fighting in Syria shifts as sectarian divisions intensify." PRI. June 12, 2013. https://www.pri.org/stories/2013-06-12/fighting-syria-shifts-sectarian-divisions-intensify Sputnik News. "UN Security Council adopts resolution on Libya.” March 18, 2011. https://sputniknews.com/world/20110318163067336/

Stack, Liam. "For Refugees From Syria, a Visit With No Expiration Date." The New York Times. November 14, 2011.https://www.nytimes.com/2011/11/15/world/middleeast/refugeesfrom-syria-settle-in-for-long-wait-in-turkey.html

Sweis, Rana F. "Jordanian Sentenced to Life in Prison for Killing 3 U.S. Soldiers." The New York Times. July 17, 2017. https://www.nytimes.com/2017/07/17/world/ middleeast/jordan-killing-us-soldiers.html?module=inline 
Telhami, Shibley. "Libya Action in U.S. National Interest." Brookings Institution. March 28, 2011. https://www.brookings.edu/opinions/libya-action-in-u-s-national-interest/

Tibon, Amir. "Iran 'Can Do What They Want' in Syria, Trump Says.” Haaretz. January 3, 2019. https://www.haaretz.com/middle-east-news/iran/iran-can-do-what-they-want-in-syriatrump-says-1.6805949

Thrall, A. Trevor. "Libya and the 5 Stages of U.S. Intervention." The National Interest. 2016. https://nationalinterest.org/blog/the-skeptics/libya-the-5-stages-us-intervention-15826

't Gilde, Lieke. "Social Network Theory in International Relations Research.” January 2014. http://arno.uvt.nl/show.cgi?fid=133127

United Nations Department of Economic and Social Affairs. "International Migration Report, 2011. ’December 2012. www.un.org/en/development//desa/population/migration/ publications/migrationreport/docs/Migration Report2011.pdf

United Nations General Assembly. "Report of the Working Group on the Universal Periodic Review: Libyan Arab Jamahiriya.” January 4, 2011. https://www2.ohchr.org/english/ bodies/hrcouncil/docs/16session/A-HRC-16-15.pdf

United Nations High Commissioner for Refugees. "Seven Facts About the Syria Crisis." March 2018. http://www.unhcr.org/ph/13418-seven-facts-syria-crisis.html

United Nations Security Council. “Resolution 1973 (2011).” March 17, 2011. https://www.nato.int/nato_static/assets/pdf/pdf_2011_03/20110927_110311-UNSCR1973.pdf

Universiteit Van Amsterdam. "Social Network Analysis." 
U.S. Central Command. "27 Feb 18: House Armed Services Committee Hearing on Terrorism and Iran FULL TRANSCRIPT.” February 27, 2018. http://www.centcom.mil/MEDIA/ TRANSCRIPTS/Votel-HASC-Testimony-27-FEB-2018/

U.S. Department of Defense. 'NBC's 'Meet the Press' interview with Secretary Gates and Secretary Clinton on Libya.” March 27, 2011. archive.defense.gov/transcripts/transcript. aspx?transcriptid $=4801$

U.S. Department of State. "Remarks at the 36th Annual Jewish Institute for National Security of America Awards Dinner.” October 10, 2018. https://www.state.gov/secretary/remarks/ 2018/10/286559.htm

Van Maanen, John. "Reclaiming Qualitative Methods for Organizational Research: A Preface." Administrative Science Quarterly, vol. 24(4). December 1979. https://www.jstor.org/stable/2392358

The Washington Post. “Trump says we're leaving Syria, 'like, very soon.' Bad idea.” March 31, 2018. https://www.washingtonpost.com/opinions/global-opinions/trump-says-wereleaving-syria-like-very-soon-bad-idea/2018/03/31/e50bb7aa-3434-11e894fa32d48460b955_story.html

Whan Choi, Seung. "What determines US humanitarian intervention?" Conflict Management and Peace Studies. vol. 3(2). 2013.

Wilkinson, Tracy. "Tillerson says U.S. military should stay in Syria and vows diplomatic push to end civil war.” January 17, 2018. https://www.latimes.com/nation/la-fg-tillerson-syria20180117-story.html

Wolfe, Alvin, \& Yang Honggang. Anthropological Contributions to Conflict Resolution. Athens: University of Georgia Press. 1996. 
Zenko, Micah. "The Big Lie about the Libyan War.” Foreign Policy. March 22, 2016. https:/foreignpolicy.com/2016/03/22/libya-and-the-myth-of-humanitarian-intervention/

Ziadeh, Radwan. "Countries at the Crossroads 2011- Syria." refworld. November 10, 2011. https://www.refworld.org/docid/4ecba6432b.html 